\author{
J. Klimentova, I. Lukes, P. Vojtisek \\ Charles University, Praha, Czech Republic \\ (E-mail: pavojt@natur.cuni.cz)
}

\title{
Conformations of Calix[4]arenes. An Investigation Based on CSD Data. Part III. Calix[4]resorcinarenes
}

\begin{abstract}
In the first part of this investigation (Part I), cone conformers of calix[4]arenes with methylene and heteroatom bridges from the Cambridge Structural Database (CSD) were investigated, in the second part (Part II) we focused on structures of partial cone, 1,2-alternate and 1,3-alternate conformers with methylene- and heteroatom-bridged calix[4]arenes represented in this Part II. This, third part (Part III) of the review is a sequel and it is on conformations and geometry of calix[4]resorcinarenes scafolds, again using the data from the CSD. The results were compared to data of calix[4]arene structures in our previous work. The effects of substitutions and inter/intramolecular interactions present in the structure on the symmetry of the resorcinarene base frame were evaluated with the help of previously introduced stereochemical parameters $\alpha, \beta$, and $\delta$. Utilization of new, slightly modified scale of parameters $\alpha^{\prime}, \beta^{\prime}, \delta^{\prime}$ was tested, too. To sum up, these parameter are useful not only for describing the geometry of calix[4]arenes, but for calix[4]resorcinarenes, too. The calix[4]resorcinarenes seem to be more conformationally flexible and the "flat» arrangements are more favoured there. Generally, the substitution is more complex and more irregular in the case of calix[4]resorcinarenes, and it is relatively difficult to found some common patterns. However, as all these results were obtained from solid state data, no conclusion concerning conformations and behavior of these molecules in solution can be stated, similary as in the case of calix[4]arenes.
\end{abstract}

Keywords: X-ray structures determination, Cambridge Structural Database (CSD), stereochemistry of calix[4]resorcinarenes, conformations, distorsion parameters, symmetry, substitution patterns, deformation of base frame.

Calix[4]resorcinarenes are a class of macrocyclic compounds which has recently attracted a lot of attention because of their possible utilization in various areas of research and industry. Because of their potential, the chemistry of resorcinarenes has in the last several years developed into a wide and well-explored area; the principal utilization of these macrocycles being as spacers bearing functional groups in a well-defined arrangement, allowing their desired cooperation, e.c. [1-4].

The utilization of calix[4]resorcinarenes as molecular platforms possesses a few advantages. First, the synthesis of these macrocycles can be easily accomplished by a well-known procedure in good yields [5]. The starting materials (resorcinol and aldehydes) are inexpensive and common. Calix[4]resorcinarenes can be easily modified on the $m$-and $p$-positions of their phenyl rings $[1,4,5]$ and even on the bridge substituents [6], which allows their chemical and physical properties to change as required. Finally, there are five possible conformations of the calix[4]resorcinarene macrocycle [4]; another advantage of using calix[4]resorcinarenes as molecular platforms.

The conformation and symmetry of the calix[4]resorcinarene molecule is important for its function as a spacer bearing substituents in a defined arrangement, which allows their interaction, interaction with cations, anions or neutral molecules [1-4]. The rigidity or flexibility of the calix[4]resorcinarene base skeleton is an important factor controlling the distances among functional groups on the resorcinarene scaffold. The geometry of the resorcinarene platform can be influenced by the interactions of its hydrophobic cavity or aromatic rings with cations or neutral molecules by the means of cation- $\pi$ interactions, $\pi, \pi$-interactions or van der Waals interactions. The substituents on the upper or lower rim may also participate in shaping of the calix[4]resorcinarene molecule; another important factor is the rigidity or flexibility of the substituents on the resorcinarene skeleton. The possible interactions (beside the above mentioned ones) may involve inter- or intramolecular hydrogen bonding, electrostatic interactions, donor-acceptor interactions (cation complexes or Lewis acid-base pairing) and sterical hindrance. In conclusion, the final shape of the calix[4]resorcinarene platform results from the combination of all these effects. Effective control of the stereochemistry of the calix[4]resorcinarene platform (e.g. fine tuning of the geometry of these molecules) is essential for its utilization in functional molecules [1-4].

In the previous two parts, of this work [7,8], influence of inter/intramolecular interactions and substitition patterns on the geometry of methylene- and heteroatom-bridged calix[4]arenes has been investigated. To enable comparison between calix[4]arene and calix[4]resorcinarene molecules, the system of ca- 
lix[4]resorcinarene and calix[4]arene conformations has been unified so the conformations of calix[4]resorcinarenes are reported as cone, partial cone, 1,2-alternate and 1,3-alternate.

Figure 1 depicts the crown, boat, diamond, saddle and chair conformations [1,4] of the resorcinarene base frame ( $m$ - and bridge substituents omitted for clarity) and, for information, the cone, partial cone, 1,2-alternate and 1,3-alternate conformations of calix[4]arenes. From Figure 1, it is obvious that the cone conformation of calix[4]resorcinarenes comprises the crown (= cone) and boat (= flattened cone) conformers. The partial cone conformation may arise either from the chair or boat conformers whereas the 1,2-alternate conformation arises from the diamond and chair conformers and 1,3-alternate conformation arises exclusively from the saddle conformers.
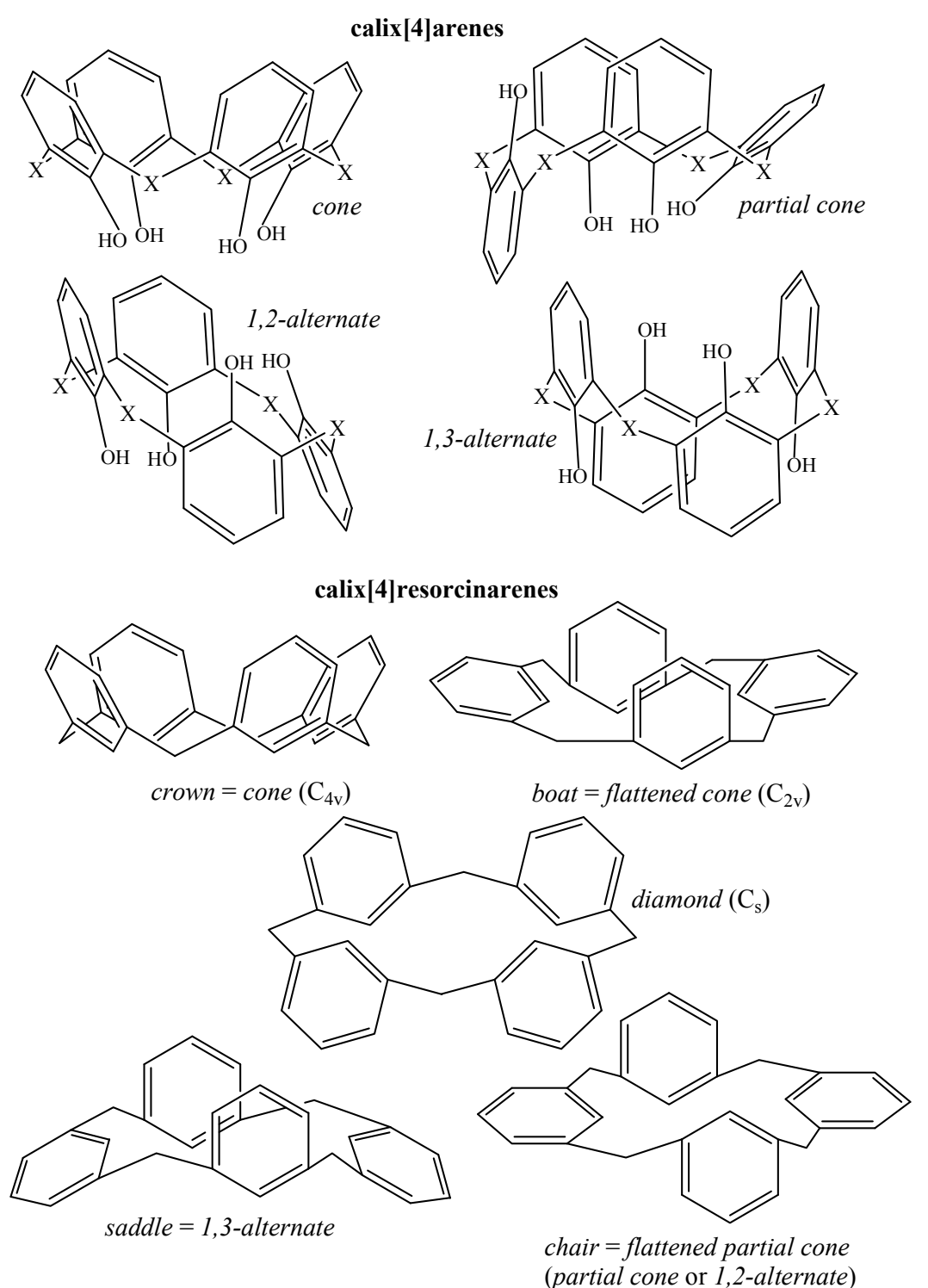

Figure 1. Possible conformations of calix[4]arenes and calix[4]resorcinarenes

(X $\ldots \mathrm{CH}_{2}$ or heteroatom/heterogroup; upper rim, $\mathrm{m}$ - and bridge substituents have been omitted for clarity)

From [1], it is clear that the substituents on the bridge carbon atoms can be arranged in axial or equatorial positions with regard to the macrocycle and transitions between these states are possible. The arrangement (axial/equatorial) of the bridge substituents will be therefore discussed in text.

To elucidate the influence of the substitution of the calix[4]resorcinarene and inter- or intramolecular interactions on the conformation of the calix[4]resorcinarene molecule, we utilized the Cambridge Structural Database [9] as the largest source of information (more than 500 of calix[4]resorcinarene structures). The conformation of the calix[4]resorcinarene molecules and inter- or intramolecular interactions present in these 
compounds can be easily determined from the crystal structure data. Nevertheless, this information may not fully correspond to the conformational behavior of the resorcinarene molecules in solution.

The number of structures (551 cif-files) obtained from CSD [9] including the distribution of calix[4]resorcinarenes according to their conformation is shown in Table 1 (for unity, the conformations of calix[4]resorcinarenes are reported as those of calix[4]arenes, e.g. cone, partial cone, 1,2-alternate and 1,3-alternate). Five duplicite cif-files (structures containing several independent molecules which belong to more than one conformation) are excluded from the total number.

Table 1

The distribution of calix[4]resorcinarenes from [9] according to their conformations (incomplete cif files are those where atom coordinates are not included)

\begin{tabular}{|l|c|c|c|c|c|c|}
\hline \multicolumn{1}{|c|}{ Conformation } & $\begin{array}{c}\text { Number of com- } \\
\text { plete cif files }\end{array}$ & $\%$ & $\begin{array}{c}\text { Number of independ- } \\
\text { ent molecules }\end{array}$ & $\%$ & $\begin{array}{c}\text { Number of in- } \\
\text { complete cif files }\end{array}$ & $\begin{array}{c}\% \\
\text { Cone }\end{array}$ \\
\hline Partial cone & 16 & 75.50 & 498 & 83.14 & 38 & - \\
\hline 1,2 -Alternate & 26 & 3.27 & Conformation & 3.51 & 1 & - \\
\hline 1,3 -Alternate & 45 & 8.17 & 27 & 4.51 & 1 & - \\
\hline Not determined & - & - & 53 & 8.85 & 0 & - \\
\hline Total & 504 & 91.47 & 599 & - & 7 & - \\
\hline
\end{tabular}

In the group of calix[4]resorcinarenes, there is a relatively large percentage of cone-structures (over $82 \%$ ) and of symmetrically substituted structures with the exception of partial cone conformers (see Table 2). In the large number of symmetrically substituted structures, the resorcinarene group resembles the group of heteroatom-bridged calix[4]arenes described in previous papers [7, 8]. Duplicite hits not excluded from Table 2; seven structures with incomplete cif files, where conformations were impossible to determine, are not included in the total number in Table 2.

Table 2

Distribution of symmetrically substituted structures in calix[4]resorcinarenes

\begin{tabular}{|c|c|c|c|c|c|}
\hline Conformation & Type & No. of cif files & $\%$ & $\begin{array}{c}\text { No. of independent } \\
\text { molecules }\end{array}$ & $\%$ \\
\hline \multirow{2}{*}{ Cone } & Symmetrically substituted & 351 & 76.6 & 383 & 76.9 \\
\hline & Other & 107 & 23.4 & 115 & 23.1 \\
\hline \multirow{2}{*}{ Partial cone } & Symmetrically substituted & 7 & 36.8 & 8 & 38.1 \\
\hline & Other & 12 & 63.2 & 13 & 61.9 \\
\hline \multirow{2}{*}{ 1,2-Alternate } & Symmetrically substituted & 25 & 92.6 & 25 & 92.6 \\
\hline & Other & 2 & 7.4 & 2 & 7.4 \\
\hline \multirow{2}{*}{ 1,3-Alternate } & Symmetrically substituted & 34 & 75.6 & 40 & 75.5 \\
\hline & Other & 11 & 24.4 & 13 & 24.5 \\
\hline Not determined & - & 7 & - & - & - \\
\hline \multirow{2}{*}{ Total } & Symmetrically substituted & 417 & 76.0 & 456 & 76.1 \\
\hline & Other & 132 & 24.0 & 143 & 23.9 \\
\hline
\end{tabular}

Unlike previously discussed calix[4]arenes [7, 8], there are substituents present on the methylene bridges of calix[4]resorcinarenes; the positions (axial/equatorial with regard to the macrocycle) of these groups significantly affect the geometry of the resorcinarene scaffold [1]. However, because of the presence of two hydroxyl groups at the $m$-positions of the upper rim (and in some cases a third hydroxyl group at the $p$-position of the upper rim), several substitution patterns not observed in the group of calix[4]arenes are possible with calix[4]resorcinarenes (e.g. molecules with $\mathrm{C}_{4}$-symmetrical substitution).

The different types of substitution are as follows: symmetrically substituted structures are those which contain symmetrically substituted all four $p$-positions, all four methylene bridges and all eight $m$-positions $\left(\mathrm{C}_{4 \mathrm{v}}\right.$-symmetrical substitution). Distally substituted structures usually contain symmetrically substituted all four methylene bridges and either symmetrically substituted all eight $m$-positions and distally substituted $p$-positions or symmetrically substituted all four $p$-positions and distally substituted both $m$-hydroxyl groups on each of two opposite resorcinarene phenyl rings $\left(\mathrm{C}_{2 \mathrm{v}}\right.$-symmetrical substitution). Molecules with 
$\mathrm{C}_{4}$-symmetrical substitution contain two groups of m-positions: 4-, 10-, 16-, 22- and 6-, 12-, 18-, 24-; each group substituted by different substituents. Molecules with other substitution patterns are usually not so numerous and are therefore not thoroughly discussed.

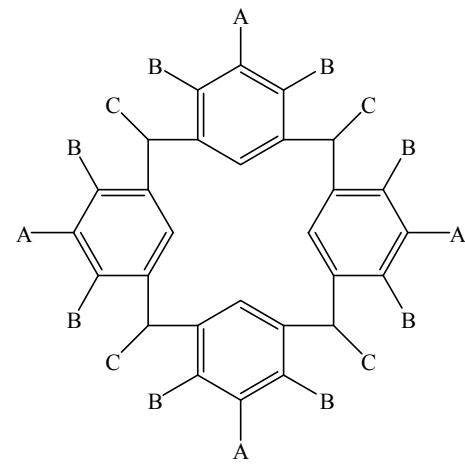

$\mathrm{C}_{4 \mathrm{v}}$-symmetrical substitution

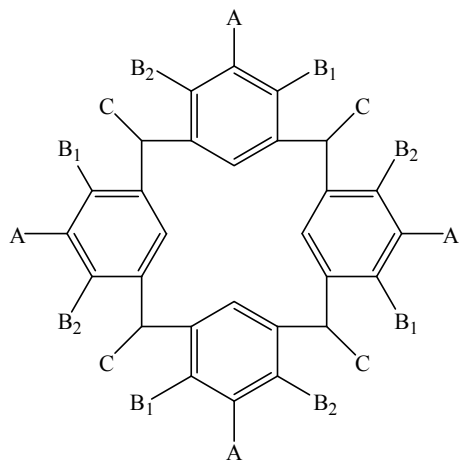

$\mathrm{C}_{4}$-symmetrical substitution

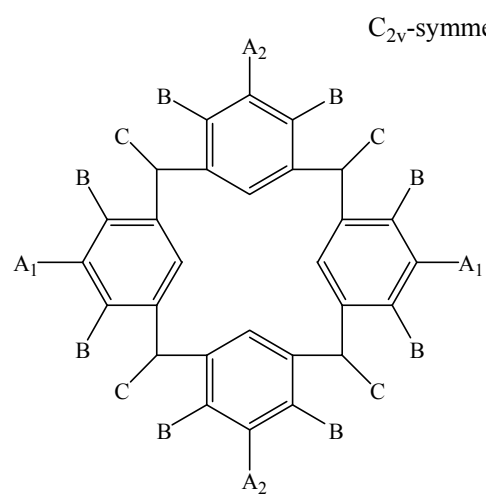

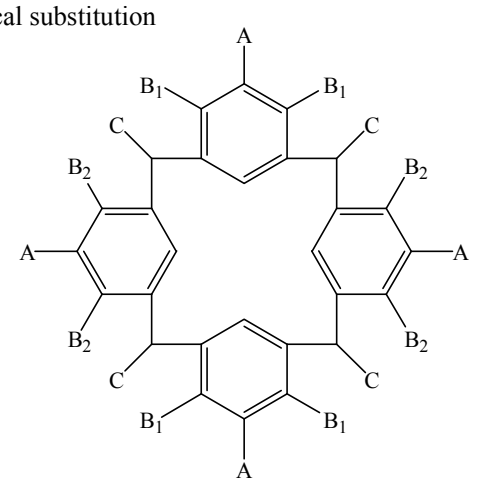

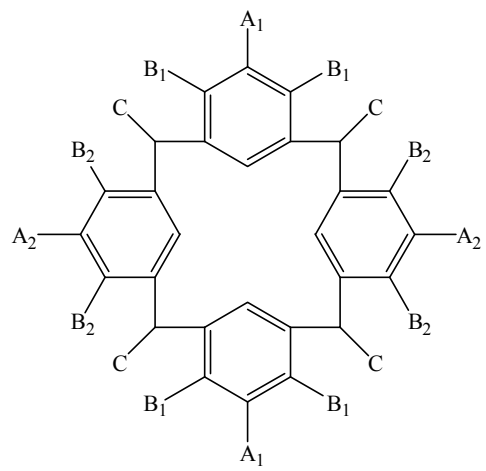

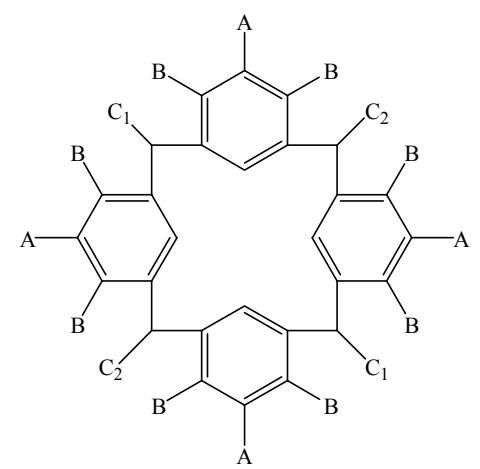

Figure 2 . The symmetry of substitution patterns in groups of calix[4]resorcinarenes $\left(A_{1} \neq A_{2}, B_{1} \neq B_{2}, C_{1} \neq C_{2}\right)$

Figure 2 shows the previously discussed types of substitution observed within the group of calix[4]resorcinarenes. The last two types for $\mathrm{C}_{2 \mathrm{v}}$-symmetrical substitution are present in a few structures only and are not common.

The group of calix[4]resorcinarenes is smaller than the group of calix[4]arenes with methylene bridges but significantly larger than the group of calix[4]arenes with heteroatom bridges (see [7, 8]). There are altogether 551 cif files belonging to this group $(23.2 \%$ from the total of 2377 cif-files in [9] belonging to calix[4]arenes with methylene and heteroatom bridges and calix[4]resorcinarenes); the number of 218 cif files for calix[4]arenes with heteroatom bridges amounts to $9.2 \%$ and for calix[4]arenes with methylene bridges (1610 cif files) to $67.7 \%$. Therefore, about one quarter of all calix[4]arene and calix[4]resorcinarene structures in [9] belongs to calix[4]resorcinarenes.

In the number of independent molecules, 1805 hits belong to calix[4]arenes with methylene bridges (67.9\% of all 2657 hits), 253 hits to calix[4]arenes with heteroatom bridges (9.5\%) and 599 hits to calix[4]resorcinarenes $(22.5 \%)$. 
From these numbers, it is obvious that calix[4]arenes with methylene bridges are the group which has attracted the most interest in research, followed by calix[4]resorcinarenes. Calix[4]arenes with heteroatom bridges are not so numerous probably because these molecules have emerged relatively recently compared to the other two groups; moreover, there are difficulties in their selective substitution, their greater conformational flexibility and stability towards aggressive chemical agents [10].

In the preceding two papers [7, 8]), the previously introduced parameters $\alpha, \beta$ and $\delta[11,12]$ have been utilized to describe the geometry of the calix[4]arene base frame. Furthermore, the utility of the parameters $\alpha, \beta$ and $\delta$ to describe the influence of inter/intramolecular interactions on the geometry of the calix[4]arene scaffold in all conformers of methylene- and heteroatom-bridged calix[4]arenes was demonstrated.

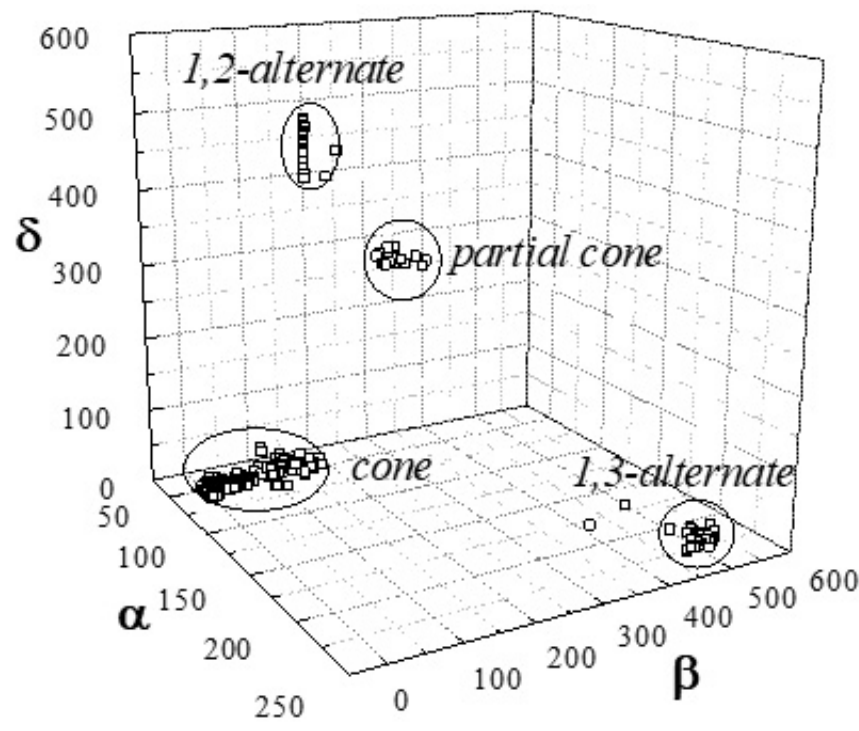

Figure 3. 3D plot of calix[4]resorcinarenes from CSD [9]

Figures 3 and 4 show 3D plots of parameters $\alpha, \beta, \delta$ of calix[4]resorcinarenes and of calix[4]resorcinarenes along with methylene- and heteroatom-bridged calix[4]arenes from [9] which were discussed in our previous works $[7,8]$. As in the case of methylene- and heteroatom-bridged calix[4]arenes, separation into distinct groups for cone, partial cone, 1,2-alternate and 1,3-alternate calix[4]resorcinarenes can be seen.

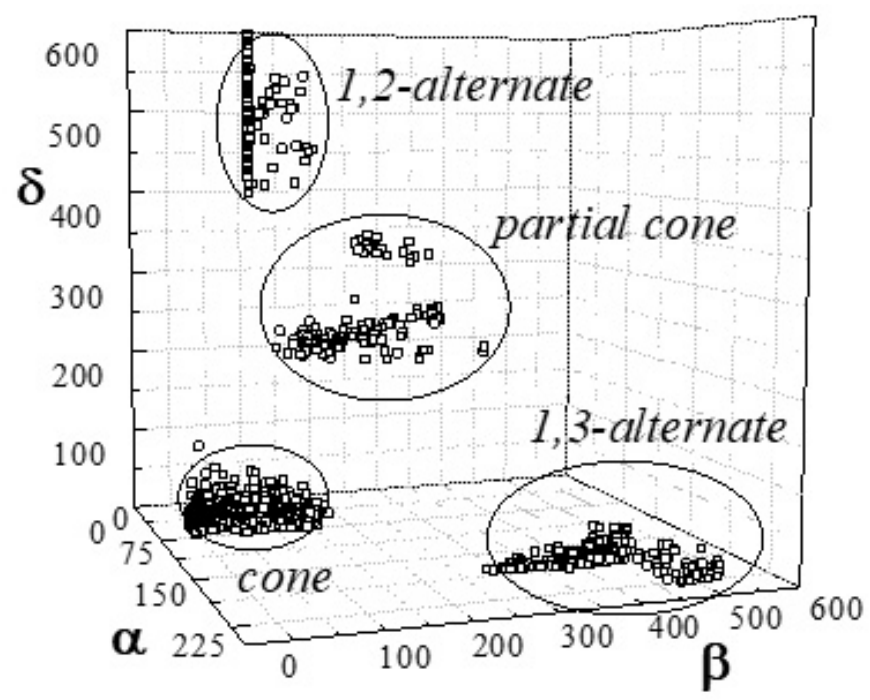

Figure 4. 3D plot of calix[4]resorcinarenes along with methyleneand heteroatom-bridged calix[4]arenes from CSD [9] 
Figure 5 shows the distribution of the $\beta, \delta$ values in the group of calix[4]resorcinarenes from [9]. Figure 6 shows similar plot for calix[4]resorcinarenes and methylene- and heteroatom-bridged calix[4]arenes from [9]. As in the groups of methylene- and heteroatom-bridged calix[4]arenes discussed previously [7, 8]), the four conformations (cone, partial cone, 1,2-alternate and 1,3-alternate) are clearly distinguished in these plots.

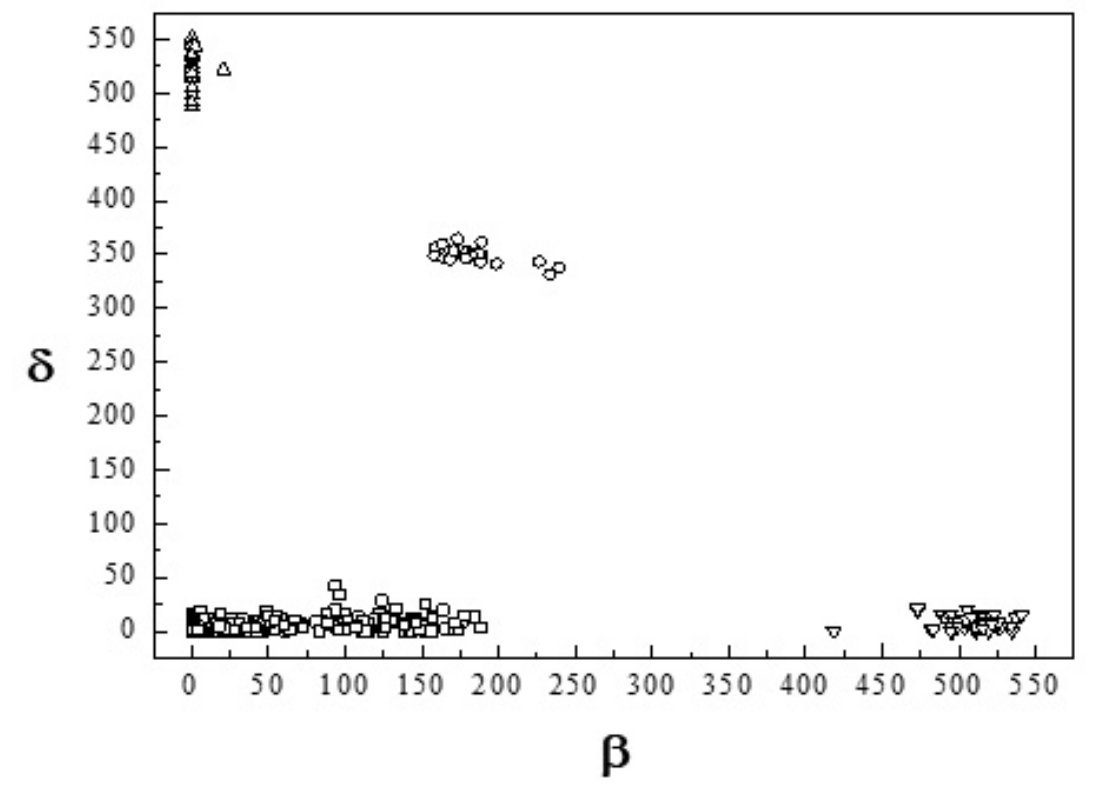

$\square-$ cone; $\circ-$ partial cone; $\Delta-1,2$-alternate; $\nabla-1,3$-alternate conformation

Figure 5. The distribution of the $\beta, \delta$ values in the group of calix[4]resorcinarenes from [9]

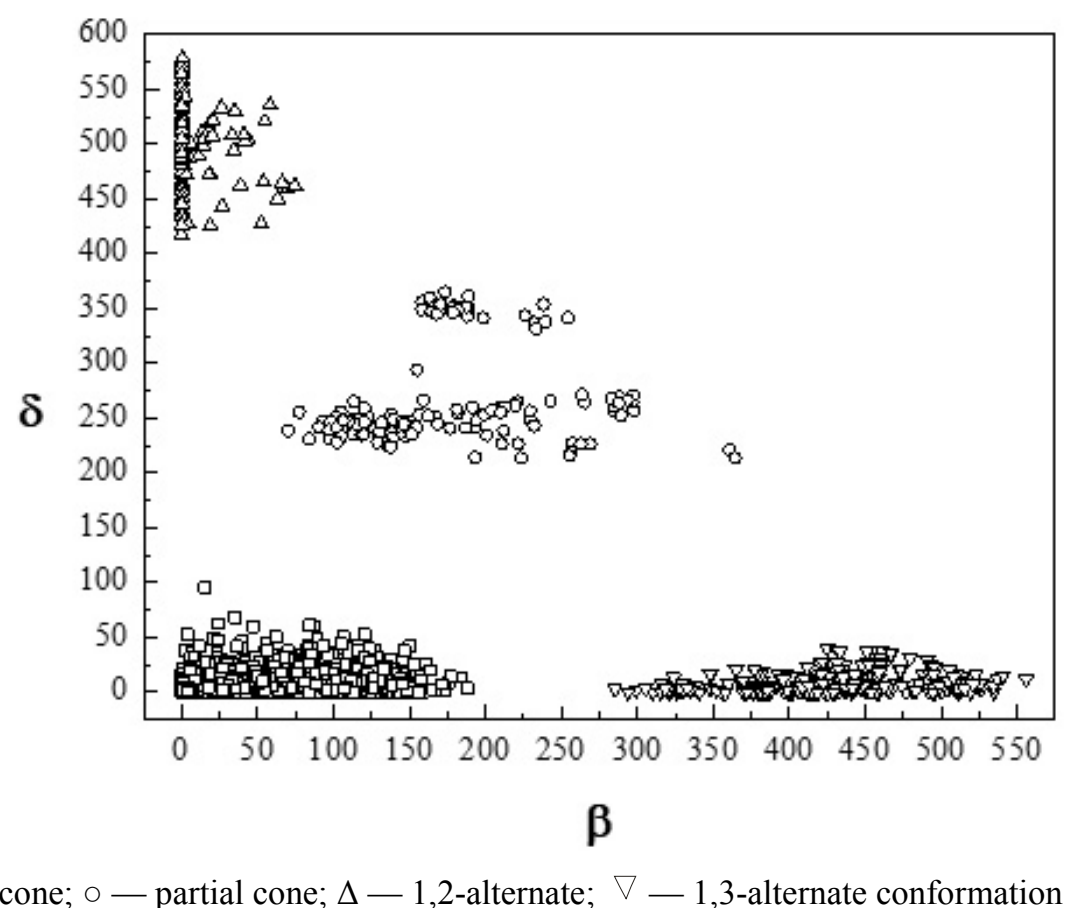

$\square-$ cone; $\circ-$ partial cone; $\Delta-1,2$-alternate; $\nabla-1,3$-alternate conformation

Figure 6 . The distribution of the $\beta, \delta$ values calix[4]resorcinarenes and methyleneand heteroatom-bridged calix[4]arenes from [9]

The average values of parameters $\alpha, \beta, \delta$ and their standard deviations in the respective groups of conformers (see Table 3) convey useful information, too. They reflect the rigidity or flexibility of the calix[4]resorcinarene skeleton as well as the distribution of the parameters $\alpha, \beta, \delta$. 
The average values of parameters $\alpha, \beta, \delta$ and their standard deviations (in)

\begin{tabular}{|l|c|c|c|c|}
\hline Conformation & Parameter & Average value AV & Standard deviation SD & SD/AV \\
\hline \multirow{3}{*}{ Cone } & $\alpha$ & 54.41 & 4.61 & 0.08 \\
& $\beta$ & 38.92 & 48.66 & 1.25 \\
& $\delta$ & 4.68 & 4.88 & 1.04 \\
\hline \multirow{3}{*}{ Partial cone } & $\alpha$ & 135.49 & 3.20 & 0.02 \\
& $\beta$ & 184.47 & 22.45 & 0.12 \\
& $\delta$ & 349.47 & 7.55 & 0.02 \\
\hline \multirow{3}{*}{ 1,2-Alternate } & $\alpha$ & 181.41 & 4.66 & 0.03 \\
& $\beta$ & 0.91 & 3.90 & 4.29 \\
& $\delta$ & 523.23 & 17.65 & 0.03 \\
\hline & $\alpha$ & 221.52 & 9.13 & 0.04 \\
& $\beta$ & 505.53 & 19.34 & 0.04 \\
& $\delta$ & 7.70 & 5.67 & 0.74 \\
\hline
\end{tabular}

From the values of the standard deviations in Table 3, it is obvious that the resorcinarenes tend to be quite uniform in all parameters and in all conformations with the exception of the cone. This behavior is caused by a relatively rigid arrangement of the resorcinarene skeleton in 1,2-alternate, 1,3-alternate and partial cone structures caused by substitution of the bridges [1]. For the cone conformation, two arrangements of the calix[4]resorcinarene base frame are possible $\left(\mathrm{C}_{4 \mathrm{v}}\right.$ or $\mathrm{C}_{2 \mathrm{v}}$ symmetry, see Figure 1 and [1]), which accounts for high value of the standard deviation in the $\beta$ parameter. The $\alpha$ parameter in the cone resorcinarenes has lower average value than in the cone calix[4]arenes with methylene or heteroatom bridge groups probably because of $m$ - substitution of the resorcinarene phenyl rings and the resulting sterical hindrance and therefore more open cavity (for comparison, see [7, 8]).

The main differences in cone, partial cone, 1,2-alternate and 1,3-alternate structures of calix[4]arenes with methylene or heteroatom bridges and calix[4]resorcinarenes which are summarized in Table 3 and in [7] can be depicted on following Figures 7-10.

From Figure 7 ( $\alpha-\beta$ plot of all cone calix[4]arene and calix[4]resorcinarene structures from [8]), it can be seen that calix[4]resorcinarenes have lower average value of the $\alpha$ parameter than the rest of calix[4]arene structures (see Table 3 in [7]). Both low and high $\beta$ values are possible in these structures; however, in calix[4]arenes with methylene or heteroatom bridge atoms the distribution of the $\beta$ values is almost continuous whereas in calix[4]resorcinarenes there are fewer structures with high $\beta$. The reason for this behavior might be hydrogen bonds between $m$ - hydroxy groups at the resorcinarene upper rim in $\mathrm{C}_{4 \mathrm{v}}$-symmetrical arrangement which are not present in significantly deformed $\mathrm{C}_{2 \mathrm{v}}$-symmetrical conformation (sterical reasons). The significantly deformed $\mathrm{C}_{2 \mathrm{v}}$ conformation is therefore not as energetically advantageous for calix[4]resorcinarenes as the less deformed $\mathrm{C}_{4 \mathrm{v}}$ conformation, which is further confirmed by relatively low average $\beta$ value for cone resorcinarenes in Table 3 .

The $\alpha-\delta$ plot of all partial cone calix[4]arenes and calix[4]resorcinarenes from [7, 9] (Fig. 8) shows that the methylene and heteroatom-bridged structures are relatively uniform (two diffuse groups can be observed within the methylene-bridged group). On the other hand, calix[4]resorcinarenes form a very distinct group at larger $\alpha$ and $\delta$. The reason for this behavior is probably absence of lower rim substituents in calix[4]resorcinarenes and therefore almost no sterical hindrance at the lower rim compared to calix[4]arene structures. The conformation of partial cone resorcinarenes is therefore close to the boat conformer depicted in Figure 1 with very close lower rim carbon atoms of two opposite phenyl rings. The only calix[4]arene structures close to this resorcinarene group are structures with missing lower rim substituents which further enhances this hypothesis [8]. Larger average values of $\alpha, \delta$ for the group of partial cone resorcinarenes are confirmed by Table 3 .

From Figure 9, it can be seen that the majority of 1,2-alternate calix[4]arenes and calix[4]resorcinarenes from $[8,9]$ have the value of the $\alpha$ parameter close to $180^{\circ}$. The only notable exception is the group of methylene-bridged calix[4] arene structures which contains a relatively large number of structures with bigger $\alpha$. Both heteroatom-bridged calix[4]arenes and calix[4]resorcinarenes form relatively distinct groups; however, as there are not so many 1,2-alternate structures compared to other conformations it is very difficult to draw any conclusions here. 


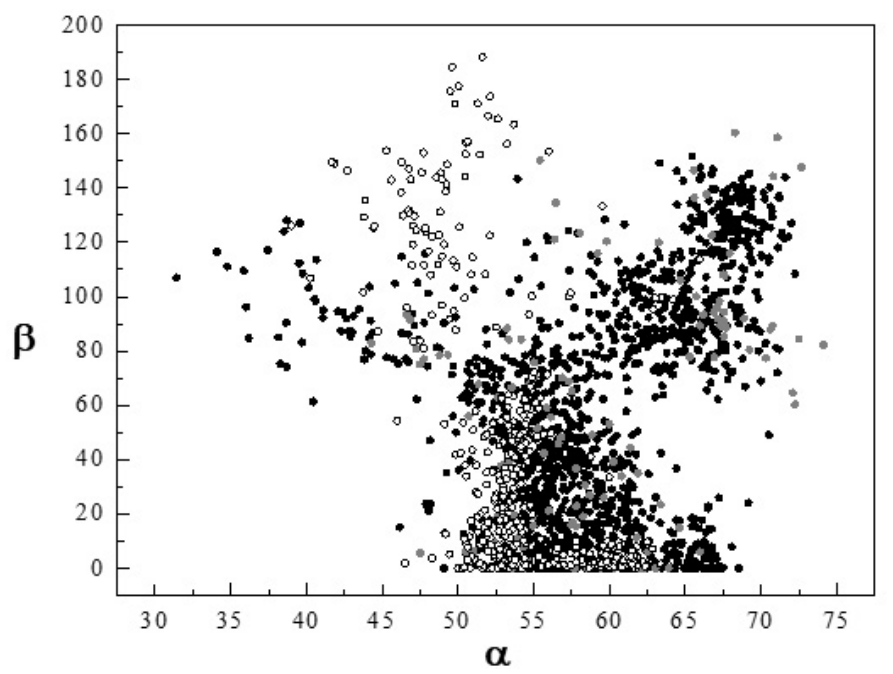

- - $\mathrm{CH}_{2}$ bridge; $\bullet$ heteroatom bridge; ○ — calix[4]resorcinarene

Figure 7. The $\alpha-\beta$ plot of the group of cone structures

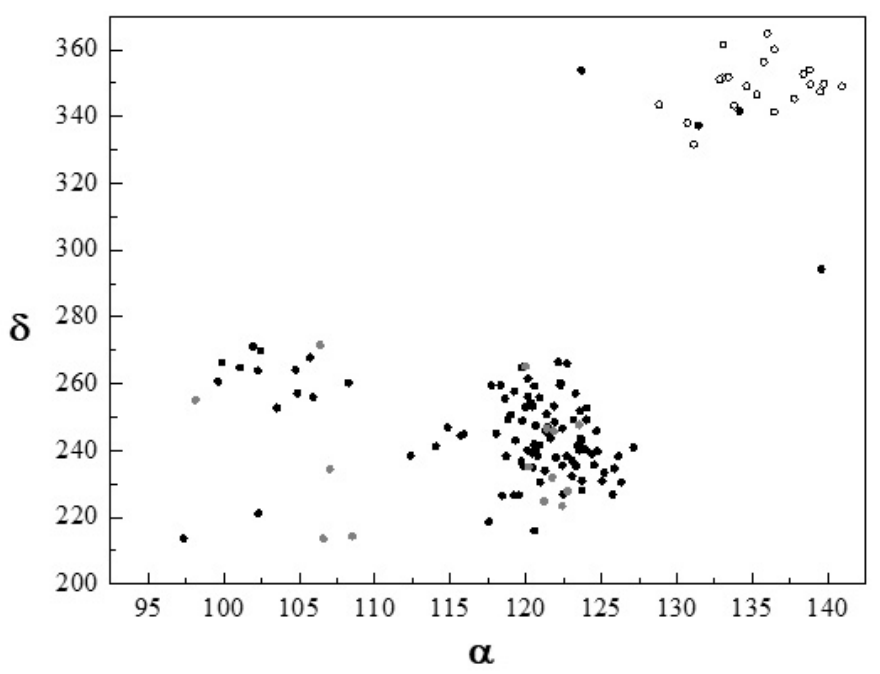

- - $\mathrm{CH}_{2}$ bridge; $\bullet-$ heteroatom bridge; ○ — calix[4]resorcinarene

Figure 8 . The $\alpha-\delta$ plot of the group of partial cone structures

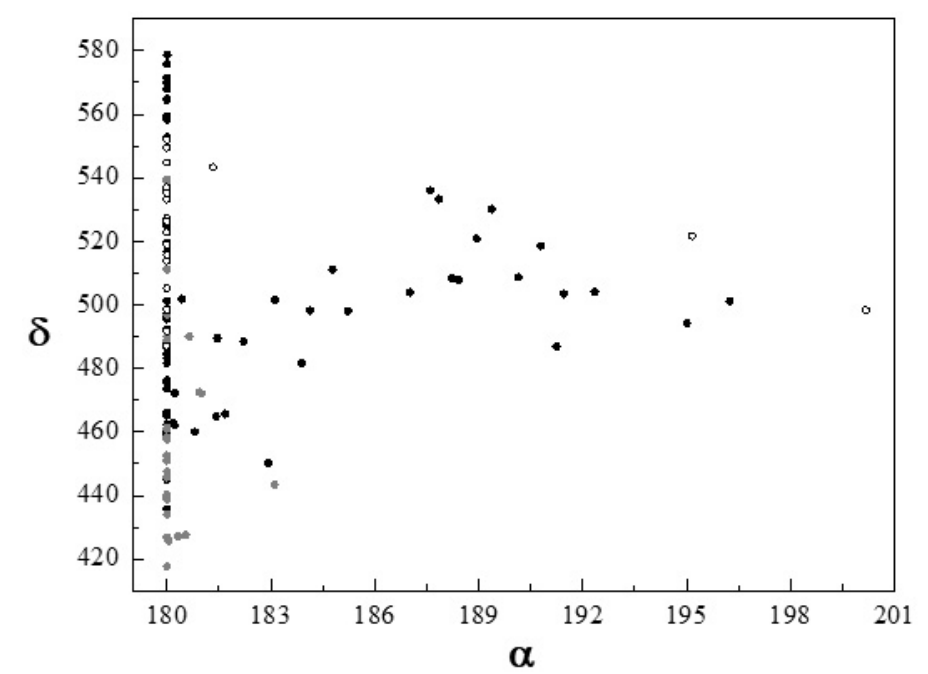

- - $\mathrm{CH}_{2}$ bridge; $\bullet$ - heteroatom bridge; ○ — calix[4]resorcinarene

Figure 9. The $\alpha-\delta$ plot of the group of 1,2-alternate structures 
The groups of 1,3-alternate calix[4]arenes with methylene and heteroatom bridges are relatively uniform (Fig. 10); a small group of methylene-bridged structures can be observed at lower $\beta$. On the other hand, calix[4]resorcinarenes form a very distinct group at high $\alpha$ and $\beta$ (see Table 3). The reason for this behavior (missing lower rim substituents) is the same as for the previously discussed partial cone structures; several methylene- and heteroatom-bridged calix[4]arenes which lack lower rim substituents have similar geometry as the resorcinarene group and are therefore close to it [8].

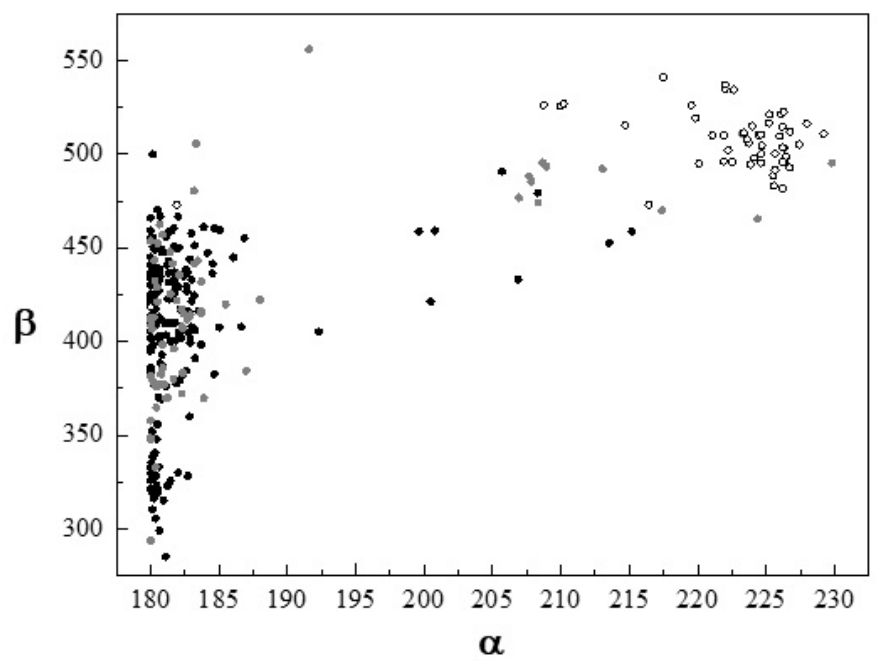

- - $\mathrm{CH}_{2}$ bridge; $\bullet$ heteroatom bridge; ○ — calix[4]resorcinarene

Figure 10 . The $\alpha-\beta$ plot of the group of 1,3 -alternate structures

The following part of this article will focus on describing the cone, partial cone, 1,2-alternate and 1,3alternate conformations of calix[4]resorcinarenes.

\section{Cone calix[4]resorcinarenes}

In the group of cone calix[4]resorcinarenes, there is a relatively large number of symmetrically substituted structures (about $77 \%$, see Table 4); complexes form $15 \%$ of the entries. This group is the most populated one in all calix[4]resorcinarenes; more than $82 \%$ of all resorcinarene structures in [9] are cone.

Distribution of substitution patterns in the cone calix[4]resorcinarenes from [9]

\begin{tabular}{|l|c|c|c|c|}
\hline \multicolumn{1}{|c|}{ Type } & $\begin{array}{c}\text { No. of cif } \\
\text { files }\end{array}$ & $\%$ & $\begin{array}{c}\text { No. of independent } \\
\text { molecules }\end{array}$ & $\%$ \\
\hline Symmetrically substituted - uncomplexed & 298 & 65.1 & 314 & 63.1 \\
\hline Symmetrically substituted - complex & 53 & 11.6 & 69 & 13.9 \\
\hline Distally substituted - uncomplexed & 29 & 6.3 & 33 & 6.6 \\
\hline Distally substituted - complex & 23 & 5.0 & 23 & 4.6 \\
\hline Other - uncomplexed & 50 & 10.9 & 53 & 10.6 \\
\hline Other - complex & 5 & 1.1 & 6 & 1.2 \\
\hline Total & 458 & 100 & 498 & 100 \\
\hline
\end{tabular}

The $\alpha-\beta$ and $\alpha-\beta$ plots of the cone group are given in Figure 11, 12. In the $\alpha-\beta$ plot, the groups of symmetrically and distally substituted molecules form two relatively distinct groups; the first one at lower $\beta$ consisting almost entirely from symmetrically substituted molecules $\left(\mathrm{C}_{4 \mathrm{v}}\right.$-symmetrical substitution), the second one at higher $\beta$ consisting both of symmetrically and distally substituted molecules $\left(\mathrm{C}_{2 \mathrm{v}}\right.$-symmetrical substitution). These two groups belong to the crown and boat conformers (see Fig. 11). 


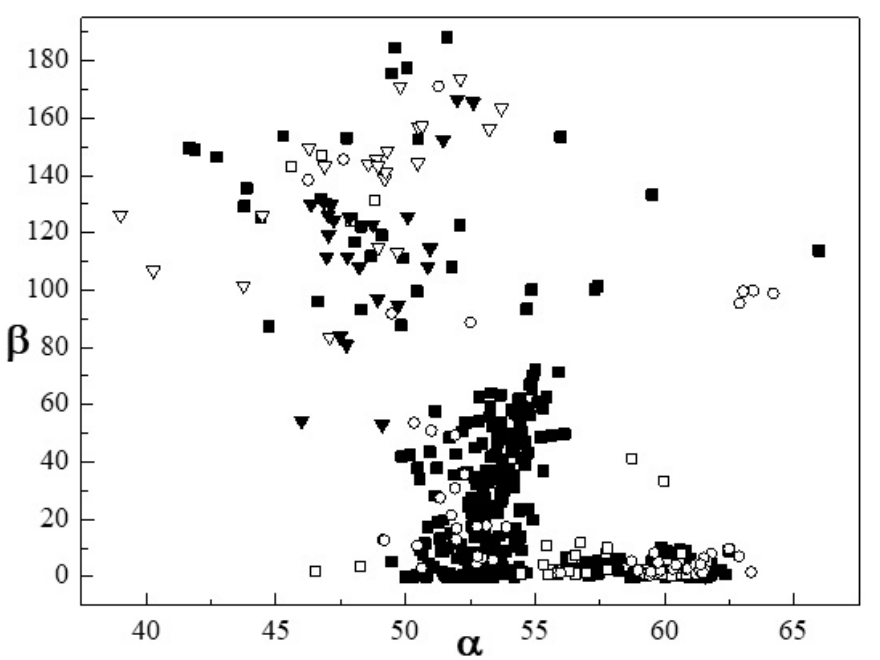

- - symmetrically substituted — uncomplexed; $\square$ - symmetrically substituted — complex;

$\boldsymbol{\nabla}$ — distally substituted — uncomplexed; $\nabla$ — distally substituted — complex;

$\circ-$ other substitution patterns — complexes not distinguished

Figure 11 . The $\alpha-\beta$ plot for the group of cone calix[4]resorcinarenes

Compared to methylene-bridged cone calix[4]arenes [7], resorcinarenes can reach relatively low $\alpha$ or very high $\beta$ values. This increased flexibility can be ascribed to missing substituents at the lower rim in resorcinarenes and therefore significantly diminished sterical hindrance at the lower rim. The parameter $\delta$ is usually below $20^{\circ}$ in the cone resorcinarene structures and the deformation towards $\mathrm{C}_{\mathrm{s}}$ symmetry is therefore usually negligible (see Fig. 12).

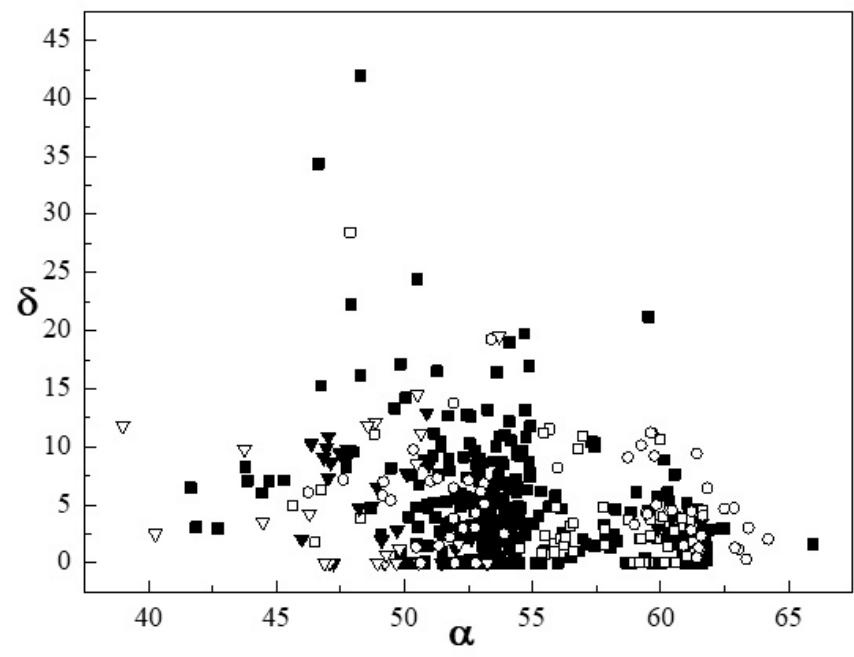

- — symmetrically substituted — uncomplexed; $\square$ — symmetrically substituted — complex;

$\nabla$ — distally substituted — uncomplexed; $\nabla$ — distally substituted — complex;

$\circ$ - other substitution patterns - complexes not distinguished

Figure 12. The $\alpha-\beta$ plot for the group of cone calix[4]resorcinarenes

The effect of a filled/empty cavity observed within the group of methylene-bridged cone calix[4]arenes [7] is present even in cone resorcinarene structures (Fig. 13). Clathrates with $\beta>75^{\circ}$ belong to flattened cone structures in which the clathrate molecule reaches only partly into the cavity. Methylene bridge substituents can be almost exclusively found in axial positions with regard to the macrocycle in all of these structures. However, an exception to this rule exists; see clathrate QENCER which has two adjacent bridge substituents in axial and the other two in equatorial positions (Fig. 14). There are only weak $\mathrm{CH}-\pi$ interactions present between the two axial aromatic substituents; no significant intermolecular interactions have been found in this structure. 


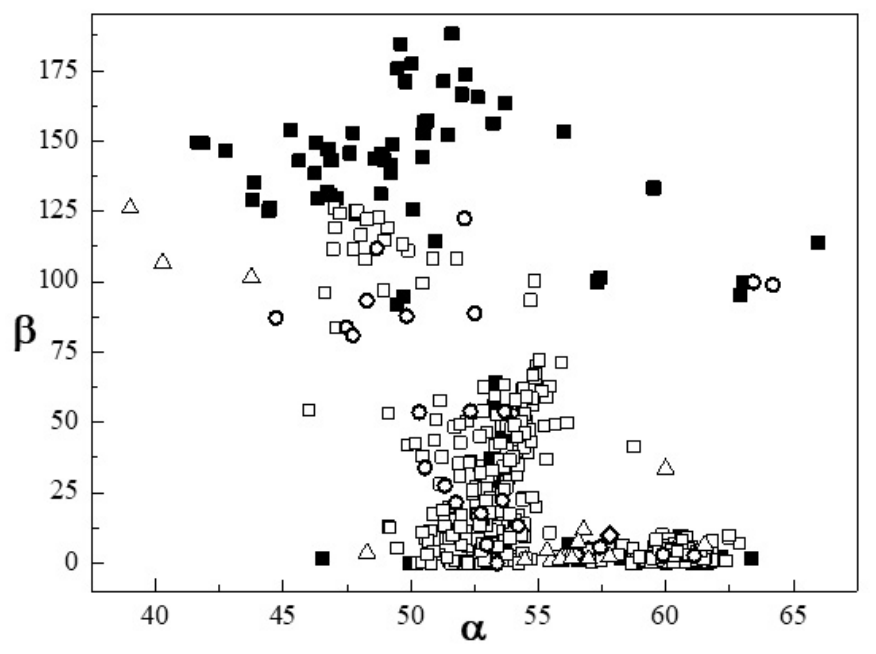

- - no molecule inside the cavity; $\diamond$ — metal ion inside the cavity; $\square$ — solvent molecule inside the cavity; $\circ$ - a part of a resorcinarene molecule inside the cavity; $\Delta$ - ligand from a complex inside the cavity

Figure 13. The effect of a filled/empty cavity in cone resorcinarenes

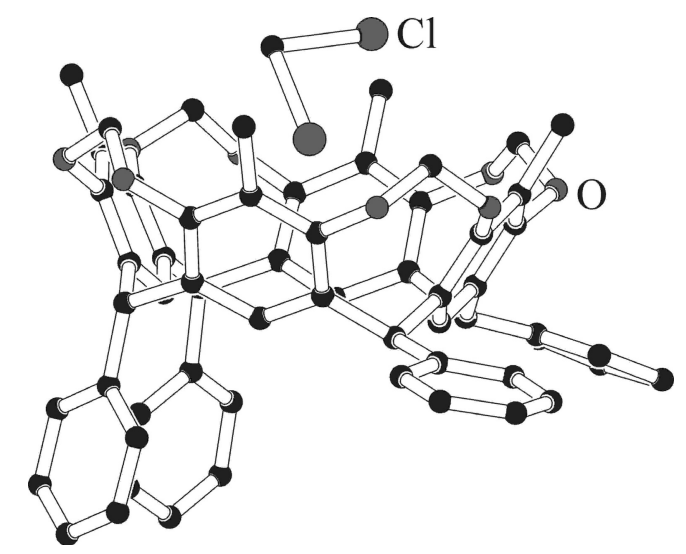

Figure 14. Structure QENCER [9]

In Figure 1, there are two possible base frames from which the conformation of cone calix[4]resorcinarenes may arise: the crown conformer and the boat (flattened cone) conformer. Regardless of the base frame substitution, structures close to the crown geometry are significantly more abundant than those of the flattened cone geometry (see Fig. 11). Structures close to the crown geometry have low $\beta$ $\left(<80^{\circ}\right)$; structures with the flattened cone geometry have lower $\alpha$ and high $\beta\left(>80^{\circ}\right.$, see the two distinct groups in Fig. 11). From Figure 11, it is obvious that the vast majority of the distally substituted structures adopt the flattened cone geometry whereas the symmetrically substituted structures can be found in both geometries; mostly in the crown one.

Since there is only a small number of complexes, the complexes will not be discussed in a separate chapter.

\section{Symmetrically substituted cone calix[4] resorcinarenes}

There are three distinct groups of symmetrically substituted calix[4]resorcinarenes in Figure 11 . The first 'cluster' (11-I with $\alpha>55^{\circ}$ and $\beta<20^{\circ}$; from 98 cif files, and 127 independent molecules, centered at [59.42; 2.94; 2.48], with standard deviation [1.95; 2.78; 2.52]) and the second one (11-II with $\alpha<55^{\circ}$ and $\beta<80^{\circ}$; from 184 cif files, 215 independent molecules, centered at $[53.12 ; 26.43 ; 4.43]$, with standard deviation $[1.39 ; 20.97 ; 3.85]$ ) are relatively 'sharp'. The third 'cluster' (11-III with $\beta>80^{\circ}$; from 37 cif files, 39 independent molecules, centered at $[49.32 ; 128.96 ; 11.08]$, with standard deviation $[5.05 ; 26.45 ; 9.37])$ is diffuse. There are, too, two complexed structures with $\alpha \sim 60^{\circ}$ and $\beta \sim 35^{\circ}$ which do not fit into these groups. 
The bulk of 'cluster' 11-I is formed by molecules which contain one-atom bridges between the adjacent upper rim $m$-hydroxyl groups $(\mathrm{C}, \mathrm{P},(\mathrm{Si})$ being the most common); there is a relatively large number of these structures (53) between the symmetrically substituted resorcinarenes. These structures adopt invariably the symmetrical crown conformation even in cases when there is no molecule inside the cavity; the reason being the rigidity of the molecule (Fig. 15). Because of the rigidity of the resorcinarene moiety and more closed cavity caused by the short upper rim bridges, the $\alpha$ parameter tends to be higher in these structures $\left(55-60^{\circ}\right)$.

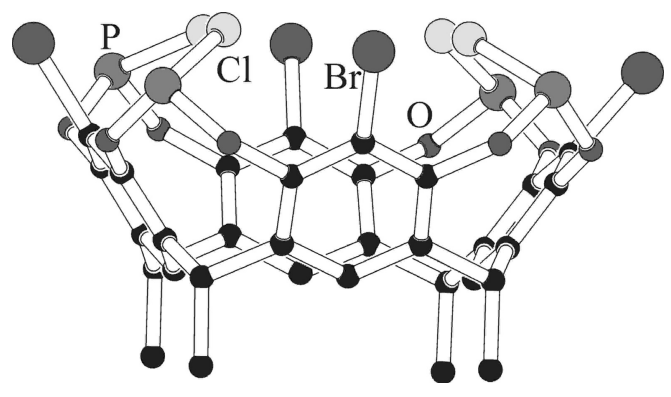

Figure 15. Structure PUHJUX [9]

'Cluster' 11-II is the most numerous group of cone resorcinarene structures and is formed by symmetrically substituted uncomplexed cone resorcinarenes which contain two or three upper rim unsubstituted hydroxyl groups. Symmetrical substitution of these molecules, cyclic array of intramolecular hydrogen bonds at the upper rim and little or no sterical hindrance at the upper rim should lead to more symmetrical structures with regard to parameters $\alpha, \beta$ and $\beta$.

Symmetrically substituted molecules with upper rim unsubstituted hydroxyl groups which adopt the more symmetrical crown conformation are usually clathrates which contain a solvent molecule inside the resorcinarene cavity; $\beta$ and $\delta$ parameters seem to be affected by the size and shape of this molecule (molecules with $\mathrm{C}_{\infty}$ axis tend to produce clathrates with $\mathrm{C}_{4 \mathrm{v}}$ symmetry $\left(\beta, \delta\right.$ about $\left.0^{\circ}\right)$, flat aromatic molecules usually result in deformation of the resorcinarene base frame towards flattened cone conformation as reflected by increase of $\beta$ (the cause being intermolecular $\mathrm{CH}-\pi$ and $\pi$, $\pi$-interactions), see Figure 16 . As in the group of cone calix[4]arenes [7], structures with disordered clathrate molecules usually have more symmetrical resorcinarene scaffolds; the disorder is therefore probably dynamic. The parameter $\alpha$ varies in these molecules but there seems to be no correlation between the size of the clathrate molecule and the value of this parameter (in the crown clathrates, $\alpha$ is typically $50-55^{\circ}$; structures deformed towards $\mathrm{C}_{2 \mathrm{v}}$ symmetry tend to have lower $\alpha$ value).

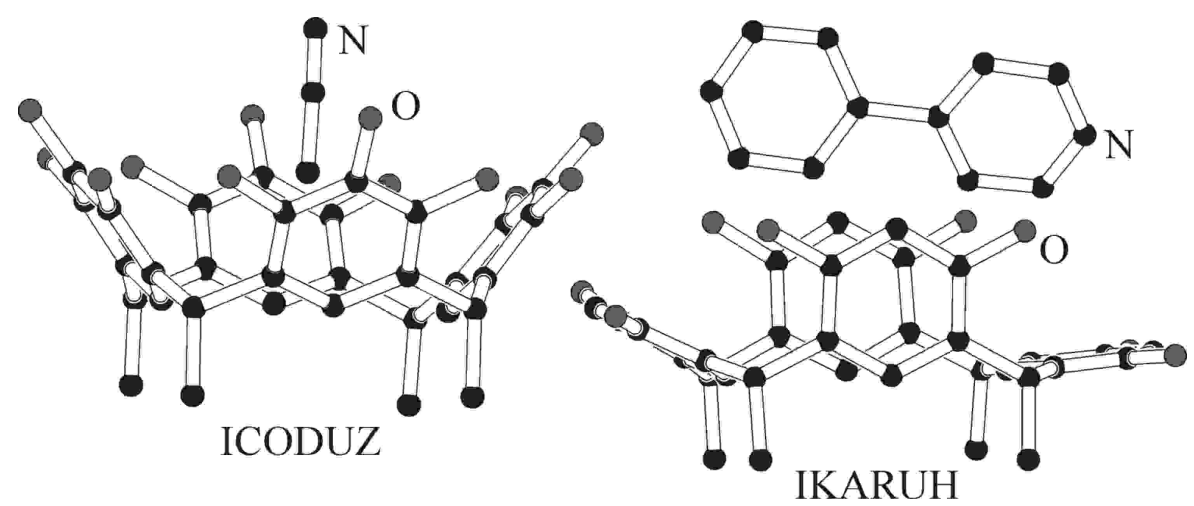

Figure 16. Structures ICODUZ, IKARUH [9]

Since calix[4]resorcinarenes with two or three hydroxyl groups at the upper rim tend to form various networks of hydrogen bonds in the solid state in addition to other commonly found intermolecular interactions ( $\pi, \pi$-interactions, $\mathrm{CH}-\pi$ interactions), the role of parameter $\delta$ which describes the deformation of the cone base frame towards $\mathrm{C}_{\mathrm{s}}$ symmetry is less transparent than in cone calix[4] where this type of hydrogen bonds is completely absent (see [7]). The value of $\delta$ parameter are therefore not discussed. 
There are also several molecules in this group which contain bulky substituents on the upper rim $p$ positions. These molecules tend to adopt the more symmetrical crown conformation even in cases where there is no solvent molecule inside the cavity. The principal reasons for this behavior seem to be sterical hindrance along with the presence of upper rim hydrogen bonds (Fig. 17).

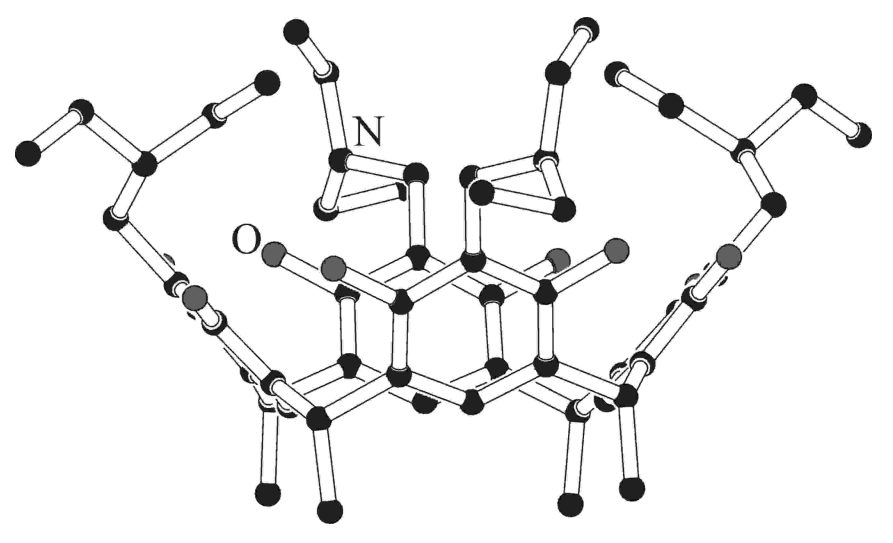

Figure 17. Structure XULJET [9]

Symmetrically substituted calix[4]resorcinarenes with upper rim unsubstituted hydroxyl groups which contain no solvent molecule inside the cavity tend to adopt the less symmetrical flattened cone conformation which maximizes favorable $\pi, \pi$-interactions between one pair of the resorcinarene phenyl rings. However, this conformation also disrupts the energetically favorable arrangement of intramolecular hydrogen bonds between the upper rim $m$ - hydroxyl groups; the final conformation is therefore either flattened cone with $\pi, \pi$-interactions or a $\mathrm{C}_{2 \mathrm{v}}$-deformed crown containing an arrangement of intramolecular hydrogen bonds in dependence on which effect is prevalent (e.g. structures FILDUA, POBCOY; Fig. 18); the flattened cone conformation is usually further stabilized by intermolecular hydrogen bonds or other interactions present in the solid state. The flattened cone structures usually belong to 'cluster' 11 -III whereas the $\mathrm{C}_{2 \mathrm{v}}$-deformed crown structures to 'cluster' 11-II.

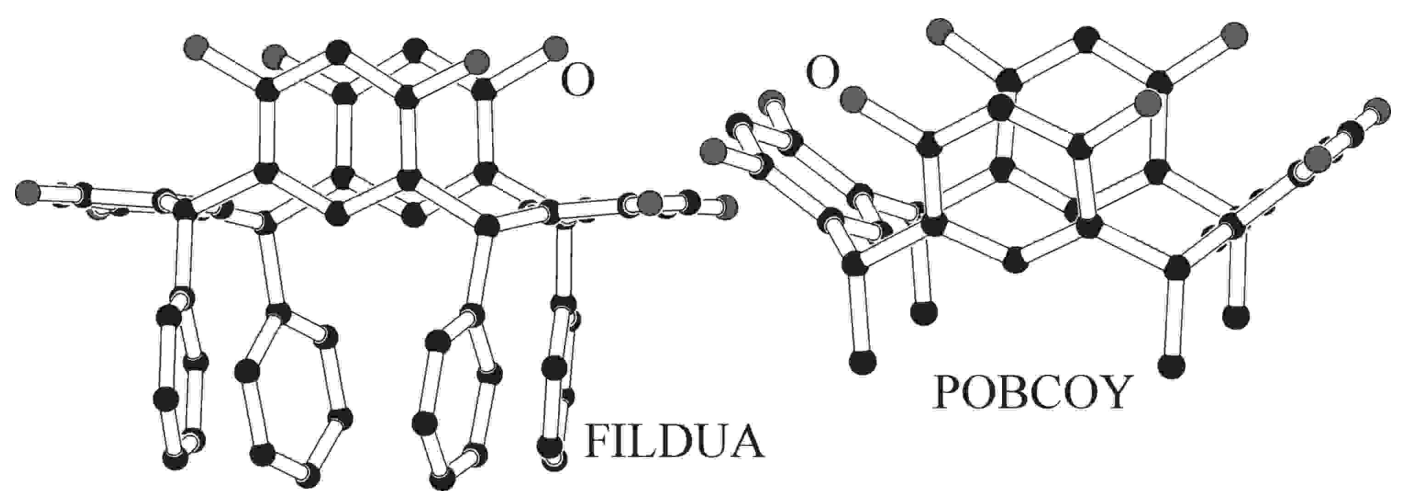

Figure 18. Structures FILDUA, POBCOY [9]

The effect of a presence of aromatic solvent in the resorcinarene cavity and the resulting deformation towards flattened cone geometry thanks to intermolecular $\mathrm{CH}-\pi$ and $\pi, \pi$-interactions has already been discussed (see Fig. 16).

The upper rim hydroxyl groups of the symmetrically substituted molecules can be alkylated or acylated; the result being 13 structures with upper rim hydroxyl groups substituted with monodentate (not bridge) groups. The conformation of these molecules is usually flattened cone due to empty resorcinarene cavity (probably sterical reasons caused by bulky upper rim substituents); these structures all belong to 'cluster' 11III. However, three structures of this group adopt more open $\mathrm{C}_{2 \mathrm{v}}$-deformed cone conformation; the causes being sterical hindrance by very large substituents at the upper rim (structure DASNAN [9]) or a solvent molecule partially reaching into the cavity (BICREL, BICRIP [9]).

The adjacent $m$ - hydroxyl groups at the upper rim can be connected even by two-atom or longer (3- or 4-atom) bridges. There are tventy symmetrically substituted structures of this type in [9]; fifteen structures 
with two-atom bridges, three structures have three-atom bridges, two structures four-atom bridges. These structures are usually clathrates with a symmetrical crown conformation; however, because of higher flexibility of the longer bridge several flattened cone molecules have been observed within this group. The absence of solvent in the cavity seems to be the main reason for the conformation of flattened cone molecules (Fig. 19), there seems to be no dependence on the number of atoms in the upper rim bridge. In dependence on the presence or absence of clathrate molecules inside the cavity, these structures belong to 'cluster' 11-II (because of the longer bridge than in structures belonging to 'cluster' 11-I, the parameter $\alpha$ is usually below $55^{\circ}$ in these structures) or to 'cluster' 11-III.

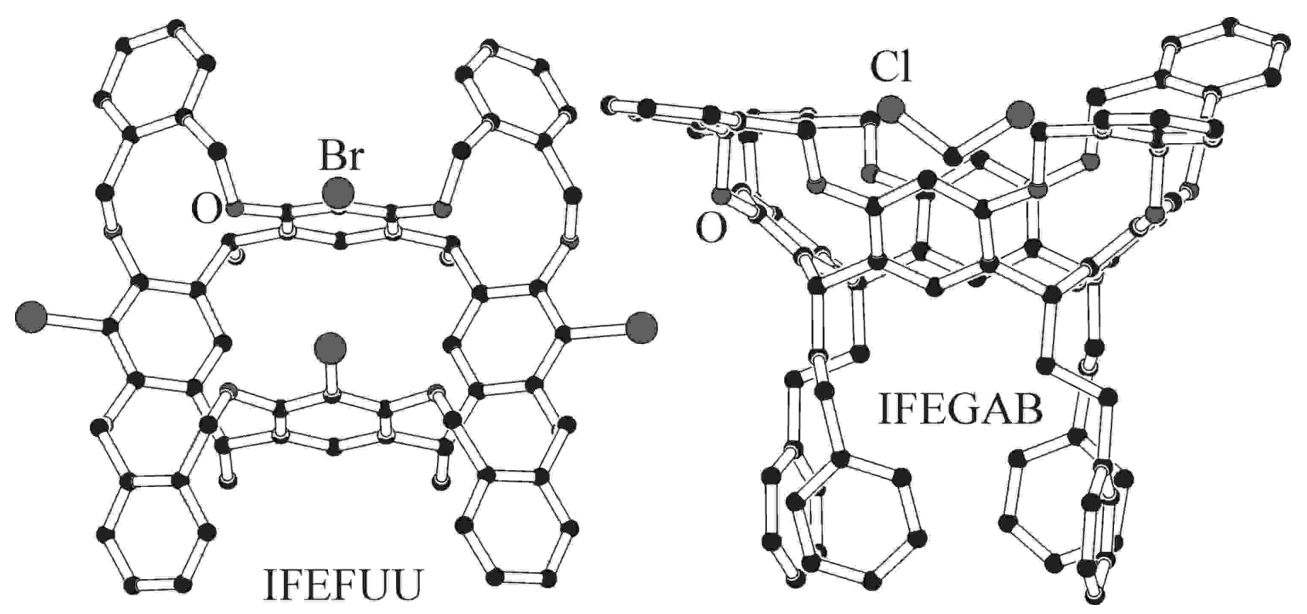

Figure 19. Structure IFEFUU and a more symmetrical clathrate IFEGAB [9]

The complexes of the symmetrically substituted resorcinarenes are quite a numerous group (53 cif-files containing 69 independent molecules). There are several coordination motives within this group.

The first group (20 cif-files) is formed by oligomeric complexes of various metal ions coordinated on resorcinarene upper rim $p$-substituents. Since the base frame is formed by resorcinarene containing methylene-bridged upper rim $m$ - hydroxyl groups and therefore is very rigid, the subsequent coordination on $p$ substituent has little effect on the geometry of the resorcinarene. The resorcinarene adopts symmetrical crown conformation in all these complexes; the $\alpha$ parameter is usually above $55^{\circ}$ in these structures with $\beta, \delta$ close to $0^{\circ}$; these structures belong to 'cluster' 11-I.

Similar structural motif is present in the second group of complexes coordinated at substituent on the upper rim $m$-methylenedioxy bridge (two structures EZIQUZ, XEBPEA [9]). Concerning the influence of the metal coordination on the resorcinarene moiety, these complexes do not differ from the previous group.

Another relatively numerous group is characterized by metal coordination on upper rim phosphorus bridges ( 21 cif-files). As in the previous cases, metal coordination has little effect on the rigid resorcinarene base frame $\left(\mathrm{C}_{4 \mathrm{v}}\right.$ symmetry in all these structures). Representative example of Ag-complex is given in Figure 20 .

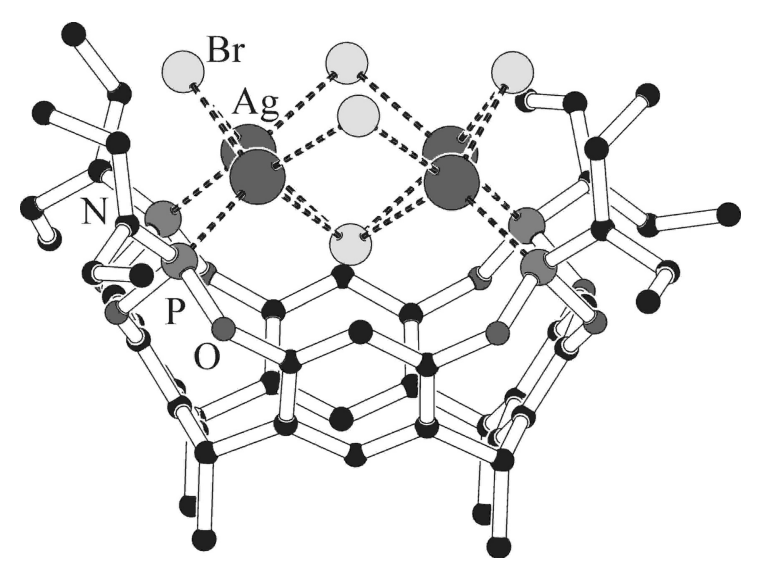

Figure 20. Structure EKUKUQ [9] 
There are also relatively symmetrical polymeric complexes coordinated directly at the upper rim $m$ - and $p$-hydroxyl groups and containing a solvent molecule inside the cavity (GALMOW, PAWKII) and monomeric complexes coordinated on the $m$-hydroxyl groups (NEFCOQ, ZUCXEA [9]; Fig. 20, 21). Because of the sterical hindrance caused by the presence of bulky ligands at the upper rim, the last two structures are more open and therefore possess low $\alpha$. These structures have low $\beta$ and belong to 'cluster' 11-I or 11-II.

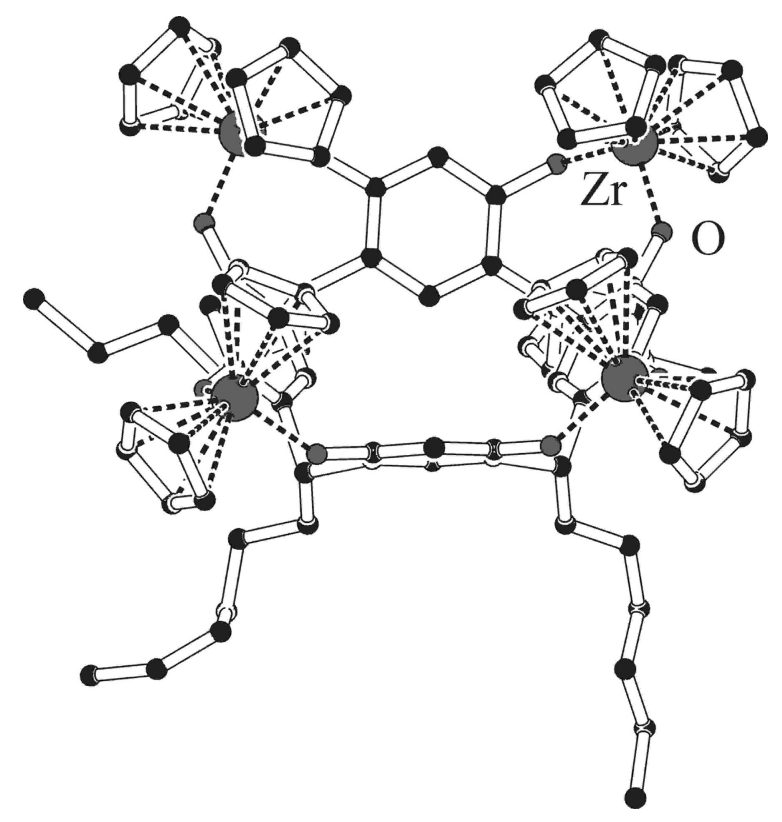

Figure 21. Structure ZUCXEA [9]

The only structure coordinated on the methylene bridge substituents is structure JADHIF (Fig. 22).

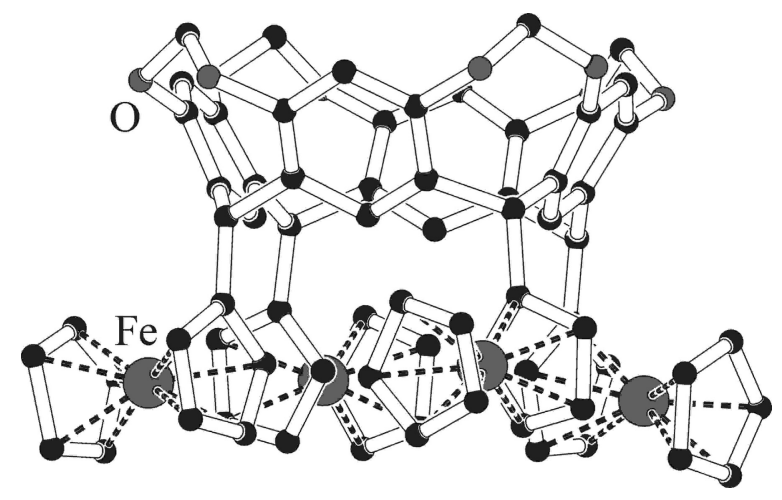

Figure 22. Structure JADHIF [9]

The only complexes with flattened cone resorcinarene base frame in the symmetrically substituted group belonging to 'cluster' 11-III are hits CALHED, UCISIJ, UCISOP and MUBSUX [9]. These structures are distally coordinated at the upper rim $p$ - substituents or $m$ - hydroxyl groups; the coordination in the first three structures requires bringing of the two opposite phenyl rings to close proximity and therefore the above-mentioned deformation of the resorcinarene moiety. Empty cavity and sterical reasons are probably behind the deformation in structure MUBSUX.

\section{Distally substituted cone calix[4] resorcinarenes}

The vast majority of distally substituted structures adopt the more deformed flattened cone conformation (Fig. 11). These structures form a diffuse 'cluster' 11-IV (48 cif-files, 51 independent molecules), centered at $[48.59 ; 127.94 ; 6.24]$, with standard deviation $[2.74 ; 23.48 ; 4.87]$. Empty cavity (and the resulting unhindered $\pi, \pi$-interaction between one pair of opposite resorcinarene phenyl rings) and sterical reasons (hindrance by bulky upper rim substituents) are behind the flattened cone conformation of the structures 
from 'cluster' 11-IV. Moreover, the substitution at the upper rim $m$ - hydroxyl groups of two opposite resorcinarene phenyl rings usually negates intramolecular hydrogen bonds (mostly sterical reasons), which also contributes to the more deformed $\mathrm{C}_{2 \mathrm{v}}$ geometry. A representative example is structure FANBUS (Fig. 23). Some exceptions with more open structure exist; structure CIMWUQ contains solvent molecule inside the cavity and has therefore $\beta \sim 55^{\circ}$, structure TAZMAJ [9] contains rigid upper rim distal bridge which forces the structure more open $\left(\beta\right.$ about $\left.80^{\circ}\right)$.

However, there are three structures in the distally $\mathrm{C}_{2 \mathrm{v}}$-substituted group (NERGIA, TOTCEK and TUCKUX [9]) with entirely different substitution pattern: methylene-bridged upper rim $m$ - hydroxyl groups with the distal substitution occurring at the $p$-positions. The geometry of these molecules is determined by the rigid base frame (methylene bridges between the adjacent upper rim $m$ - hydroxyl groups, see similar structures in the symmetrically substituted group) and these structures are therefore close to structures from 'cluster' 11-I from the symmetrically substituted group.

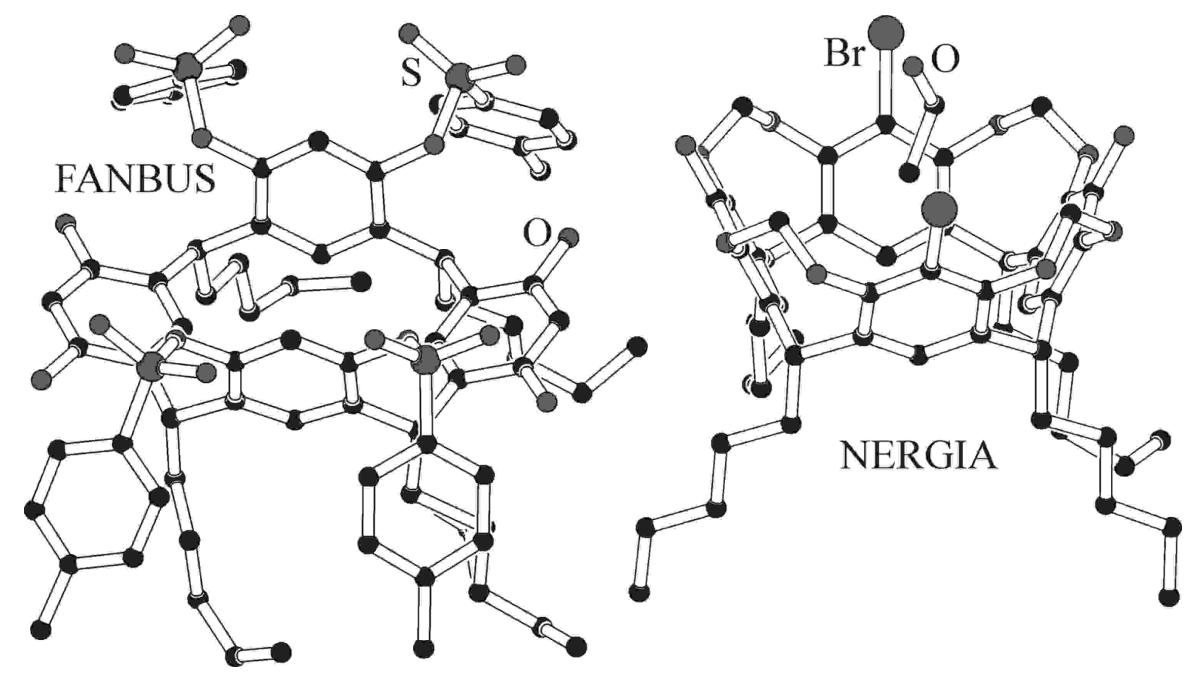

Figure 23. Structures FANBUS, NERGIA [9] reflecting two typical substitution patterns within the distally substituted group; the distal substitution in the first case may take place at either pair of the phenyl rings (either on the closer pair or on the more distant one)

There are a relatively large number of complexes within the distally substituted group ( 23 structures out of the total of 52 hits for the distally substituted group which amounts to $44 \%$ ). All complexes are derived from the structures distally substituted at the $m$-hydroxyl groups of two opposite resorcinarene phenyl rings. Since the coordination invariably takes place at these substituents and does not therefore affect the resorcinarene moiety directly, all structures in this group are deformed towards the $\mathrm{C}_{2 \mathrm{v}}$ geometry exactly as their uncomplexed counterparts. Structures containing solvent molecule within the cavity (ALEPEM, ALEPIQ [9]) are somewhat more open as are structures distally coordinated by a bulky metal cluster at the upper rim substituents of the closer phenyl rings (ARUJUS, OMAKOC, OMAKUI [9]); the listed effects are reflected in lower $\beta$ value for these structures.

\section{Structures with less symmetrical substitution patterns}

The groups with other substitution patterns are the least numerous, each containing several structures only. The $\alpha-\beta$ and $\alpha-\delta$ plots for these cone calix[4]resorcinarenes are given in Figure 24 and 25, respectively.

The structures with $\mathrm{C}_{4}$-symmetrical substitution form a relatively uniform group with $\alpha<55^{\circ}$ ('cluster' 24-I, 15 cif-files contain 16 independent molecules, centered at $[51.76 ; 21.98 ; 5.53]$ with standard deviation $[1.07 ; 15.83 ; 5.07])$. There are two structures with $\beta>80^{\circ}$ which do not belong into this group. Structures from the 'cluster' 24 -I contain one substituted $m$-hydroxyl group on each resorcinarene phenyl ring and possibly even substituted $p$-positions of these phenyl rings (for the two possible substitution patterns; see Fig. 26). Since the vast majority of these molecules exist in the crown conformation thanks to presence of a solvent molecule inside the cavity, this group is very close to the' cluster' 11-II of the symmetrically substituted crown resorcinarenes. 


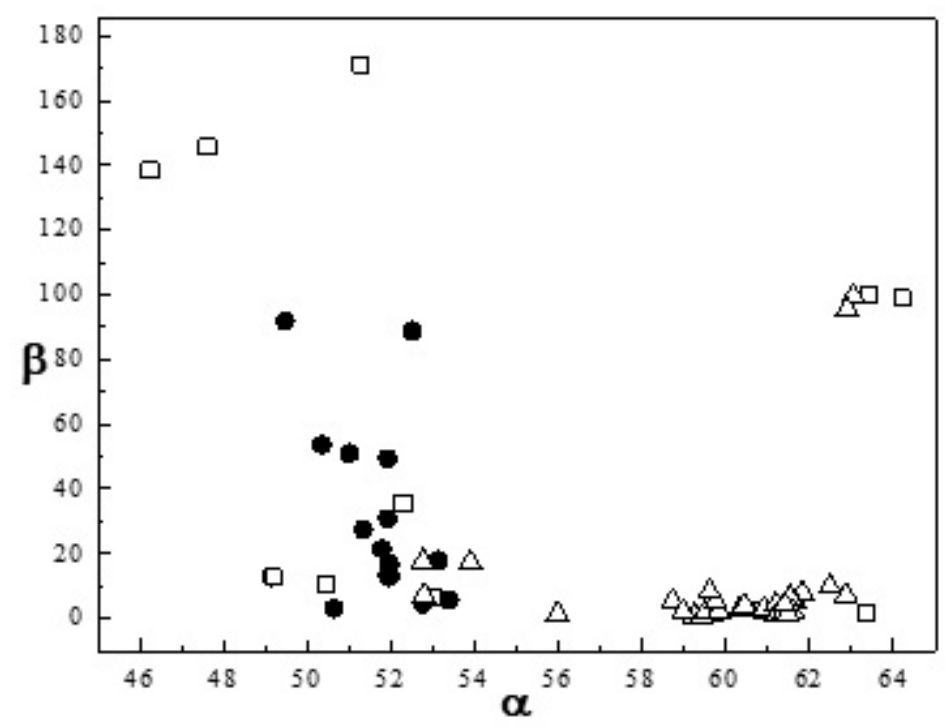

- - molecules with $\mathrm{C}_{4^{-}} ; \square-\mathrm{C}_{2^{-}} ; \Delta-\mathrm{C}_{\mathrm{s}}$-symmetrical substitution pattern

Figure 24 . The $\alpha-\beta$ plot for the less symmetrically substituted cone calix[4]resorcinarenes

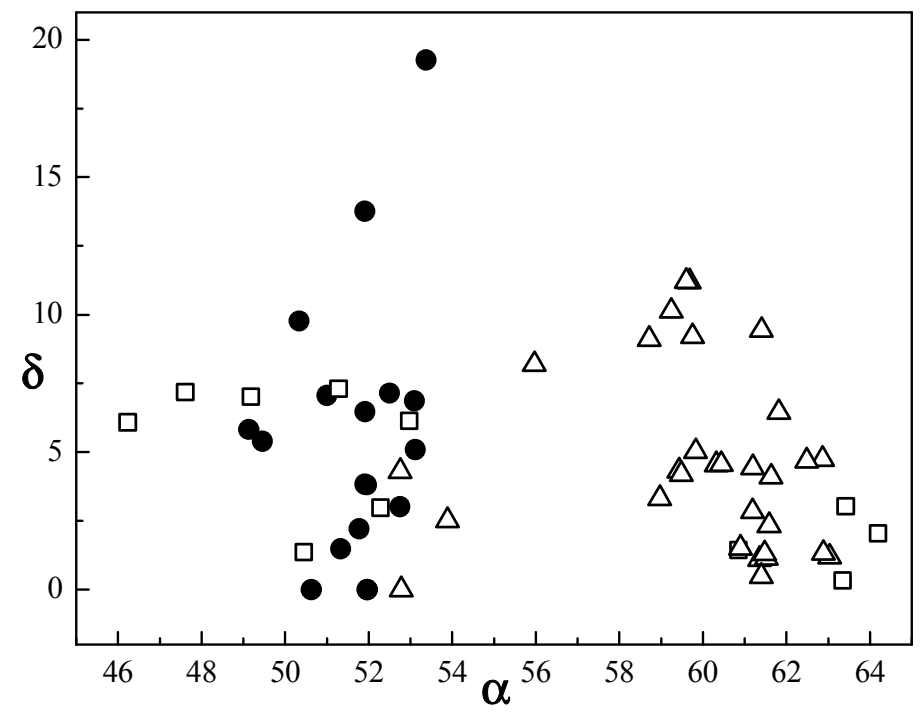

- - molecules with $\mathrm{C}_{4^{-}} ; \square-\mathrm{C}_{2^{-}} ; \Delta-\mathrm{C}_{\mathrm{s}}$-symmetrical substitution pattern

Figure 25. The $\alpha-\delta$ plot for the less symmetrically substituted cone calix[4]resorcinarenes

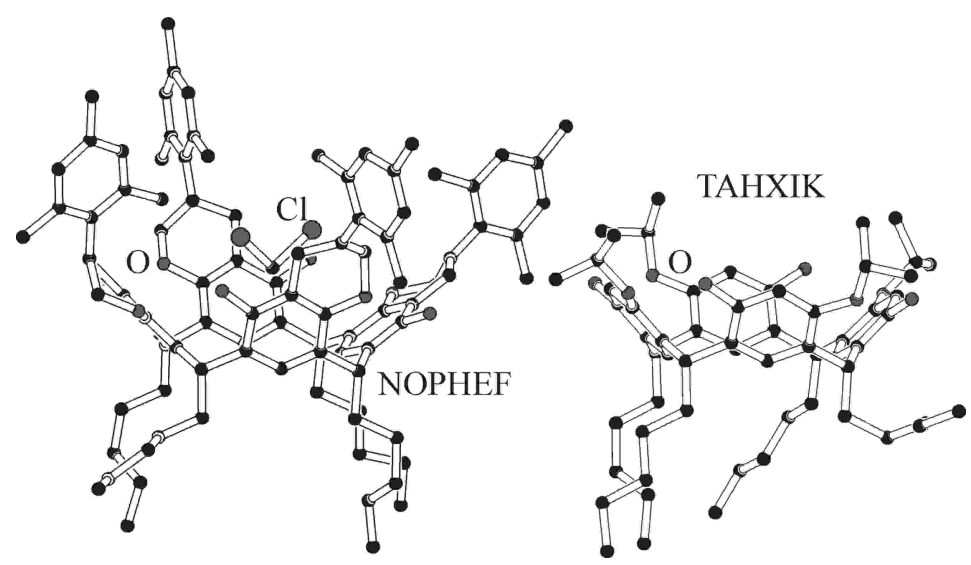

Figure 26. Structures NOPHEF, TAHXIK [9] 
The group of $\mathrm{C}_{2}$-symmetrically substituted resorcinarenes is a very diverse one, varying widely in substitution patterns. There are a number of proximally bridged structures in this group, either on the upper rim or on methylene bridges. The more symmetrical of these structures usually contain a solvent molecule inside the cavity, the result being crown conformers ('cluster' 24-II, 6 cif-files with 6 independent molecules, centered at $[54.85 ; 11.65 ; 3.21]$ with standard deviation $[5.32 ; 11.43 ; 2.52])$. The same effect was observed with methylene-bridged upper rim $m$-hydroxyl groups (Fig. 27). On the other hand, unoccupied cavity tends to result in flattened cone conformers ( 3 cif-files with 5 independent molecules).

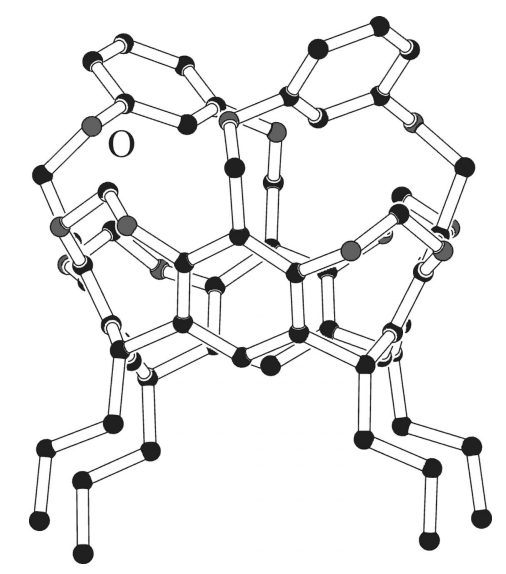

Figure 27. Upper rim proximally bridged structure ASAWEW [9] with a rigid resorcinarene base frame

The group of the $\mathrm{C}_{\mathrm{s}}$-symmetrically substituted structures is likewise quite diverse; the majority of molecules contain methylene-bridged upper rim $m$ - hydroxyl groups which accounts for their rigidity and crown conformation close to the 'cluster' 11-I of the symmetrically substituted group (the compact group in Figure 24 at $\alpha>58^{\circ}$ and $\beta<20^{\circ}$ : the 'cluster' 24-III, 16-cif files containing 24 independent molecules, centered at [60.68; 3.77; 5.06]; with standard deviation $[1.12 ; 2.57 ; 3.25])$. There are also several structures with upper rim two-atom bridges; these molecules have $\alpha<56^{\circ}$ and adopt the crown conformation as well. Other structures from this group are few and not so important to be discussed explicitely.

\section{Partial cone calix[4]resorcinarenes}

In the group of partial cone calix[4]resorcinarenes, there is a relatively low percentage (about $37 \%$ ) of symmetrically substituted structures compared to the rest of calix[4]resorcinarenes (see Table 5). Moreover, this group is the least populated one (19 cif-files containing 21 independent molecules only). On the other hand, the number of complexes in this group is relatively big (6 structures).

Table 5

Distribution of substitution patterns in the group of partial cone resorcinarenes from [9]

\begin{tabular}{|l|c|c|c|c|}
\hline \multicolumn{1}{|c|}{ Type } & $\begin{array}{c}\text { No. of cif } \\
\text { files }\end{array}$ & $\%$ & $\begin{array}{c}\text { No. of independent } \\
\text { molecules }\end{array}$ & $\%$ \\
\hline Symmetrically substituted — uncomplexed & 6 & 31.6 & 7 & 33.3 \\
\hline Symmetrically substituted - complex & 1 & 5.3 & 1 & 4.8 \\
\hline Distally substituted - uncomplexed & 4 & 21.1 & 5 & 23.8 \\
\hline Distally substituted - complex & 5 & 26.3 & 5 & 23.8 \\
\hline Other - uncomplexed & 3 & 15.8 & 3 & 14.3 \\
\hline Total & 19 & 100 & 21 & 100 \\
\hline
\end{tabular}

There are two possible conformations from which partial cone calix[4]resorcinarenes may arise (Fig. 1): boat (flattened cone) or chair (flattened partial cone) conformation. The difference between these two possibilities is straightforward (see Fig. 1). However, only conformers derived from the boat conformation have been observed within this group; substituents on the methylene bridges are in all structures from this group arranged in axial positions with regard to the macrocycle. Moreover, $\pi, \pi$-interaction is usually present between one pair of the opposite resorcinarene rings (with the exception of several 'clathrates'). 

and 29 .

The $\alpha-\beta$ and $\beta-\delta$ plots for the group of partial cone calix[4]resorcinarenes are depicted in Figures 28

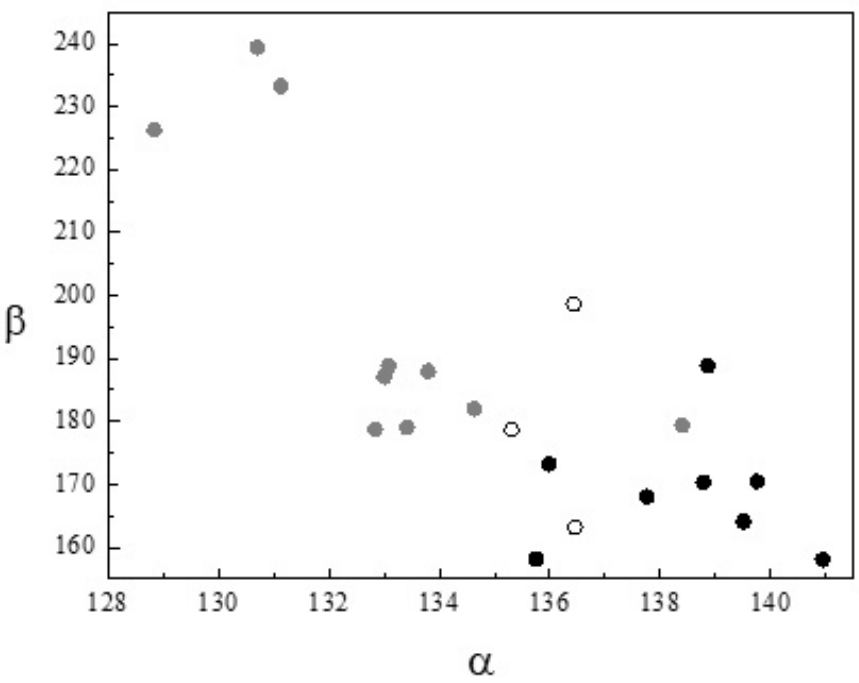

- - symmetrically substituted; $\bullet$ - distally substituted; ○ — other substitution patterns

Figure 28. The $\alpha-\beta$ plot for the group of partial cone calix[4]resorcinarenes

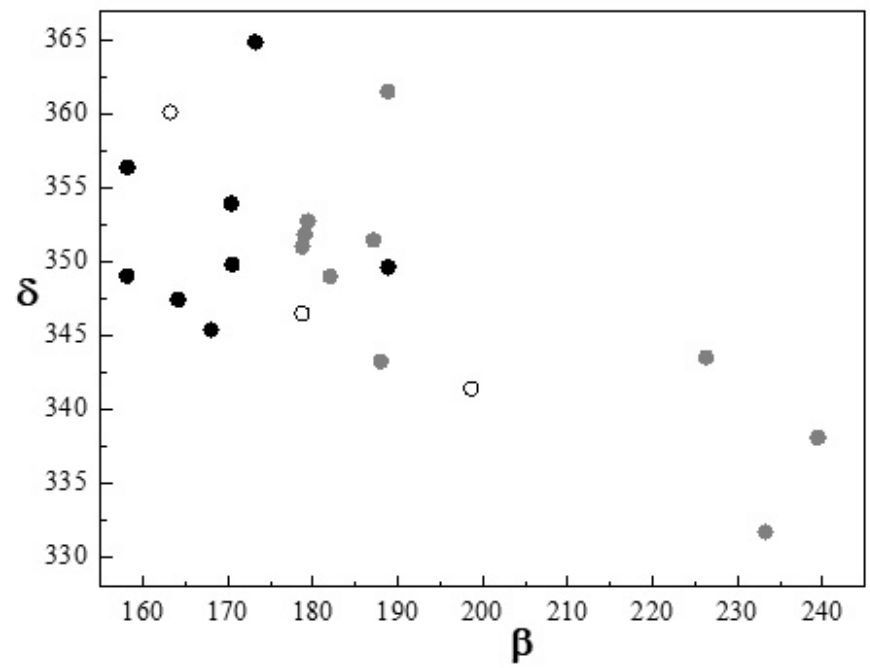

- — symmetrically substituted; $\bullet$ - distally substituted; ○ — other substitution patterns

Figure 29. The $\beta-\delta$ plot for the group of partial cone calix[4]resorcinarenes

The diffuse 'cluster' of symmetrically substituted structures ('cluster' 28-I) contains 6 cif-files with 8 independent molecules and is centered at $[138.42 ; 168.92 ; 352.07]$ with a standard deviation of $[1.70 ; 9.21$; 5.83]. The main group of the distally substituted structures ('cluster' 28-II) consists of 6 cif-files with 6 independent molecules which have $\beta<200^{\circ}$ and $\alpha<136^{\circ}$; this cluster is centered at [133.46; 183.95; 351.37] with a standard deviation of $[0.61 ; 4.18 ; 5.40]$.

From Figures 28 and 29, it can be seen that the group of symmetrically substituted molecules ('cluster' 28-I) is relatively uniform in all parameters, the opposite being true with the distally substituted structures. Because of small number of structures in the symmetrically substituted group, diversity of the structures and variety of inter- and/or intramolecular interactions present in the solid phase (hydrogen bonds in structures with upper rim hydroxyl groups, $\mathrm{CH}-\pi$ and $\pi, \pi$-interactions with solvent molecules, metal coordination etc.), no correlation between the type of substituents and geometry of the resorcinarene moiety has been found. 
Solvent molecules do not enter the 'cavity' in this group and therefore do not disrupt the $\pi, \pi$-interactions between two opposite resorcinarene rings in this group; this effect results in more closed structures with lower $\beta$. The representative example of this group is structure YABYAC (Fig. 30).

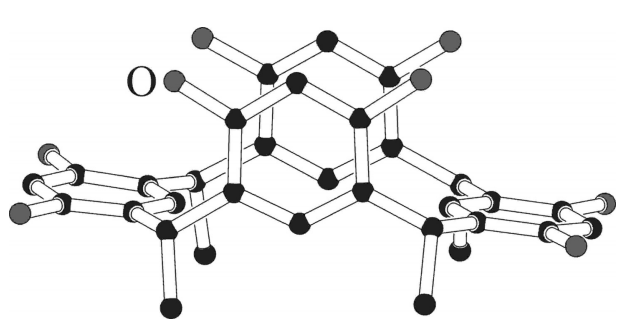

Figure 30. Structure YABYAC [9]

Resorcinarenes within the distally substituted group differ most significantly in parameter $\beta$. The main reason behind this behavior is the presence or absence of solvent molecule inside the resorcinarene 'cavity'. Structures which contain solvent molecule inside the 'cavity' have larger $\beta$ because of more open structure caused by disruption of intramolecular $\pi, \pi$-interactions. Another reason for more open 'cavity' is distal bridging of the upper rim by a rigid substituent. These effects lead to $\beta>220^{\circ}$. However, in the majority of the distally substituted structures ('cluster' 28 -II) intramolecular $\pi, \pi$-interactions are not disrupted and the parameter $\beta$ is close to the symmetrically substituted group.

Complexes within the distally substituted group are coordinated at upper rim phosphorus-bearing substituents and display a variety of coordination modes. As a whole, these compounds are of little interest.

The previously-mentioned effect of a filled/empty 'cavity' is depicted in Figure 31. The base conformation of the resorcinarene base frame is boat, 'clathrate' molecules (if any) usually reach only partly into the 'cavity'. As in the groups of partial cone calix[4]arenes [7], 'clathrates' have bigger $\beta$ than molecules with empty 'cavity'. Since there are only a few structures in the group of partial cone resorcinarenes, it is difficult to draw any conclusions regarding the influence of substitution and inter-/intramolecular interactions on the geometry of the resorcinarene scaffold.

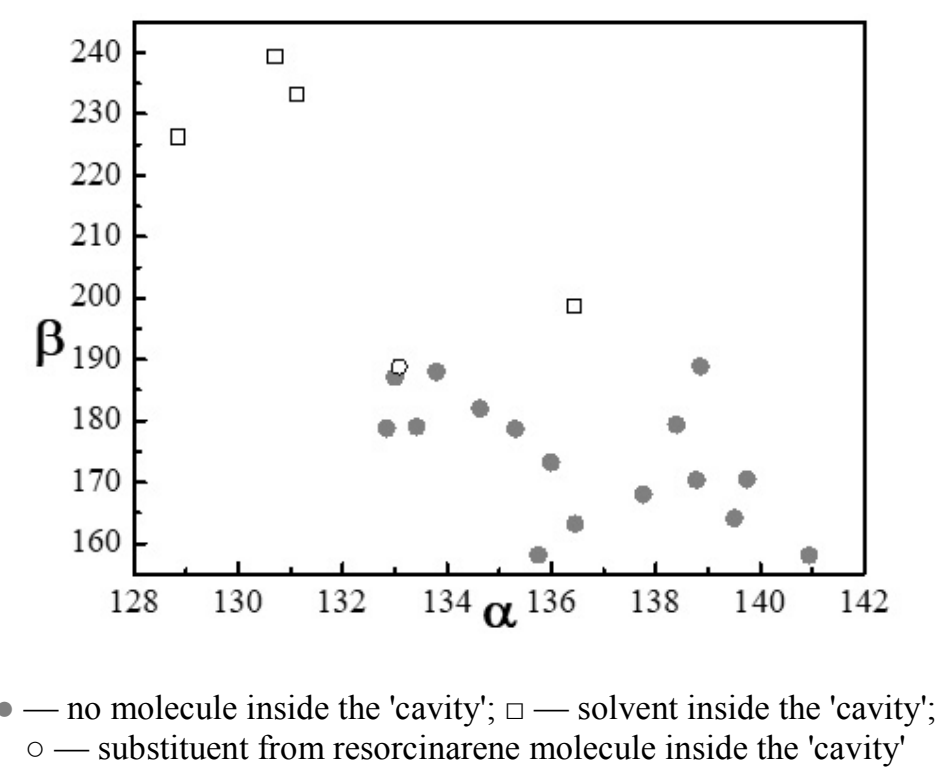

Figure 31. The effect of a filled/empty 'cavity' in partial cone resorcinarenes

\section{1,2-alternate calix[4]resorcinarenes}

The relatively scarcely populated group of 1,2-alternate calix[4]resorcinarenes is unique in two respects. First, it contains very large percentage of symmetrically substituted structures ( 25 out of 27 hits, see Table 6). Next, there are no complexes within this group. 
Distribution of substitution patterns in the group of 1,2-alternate resorcinarenes from [9]

\begin{tabular}{|l|c|c|c|c|}
\hline \multicolumn{1}{|c|}{ Type } & $\begin{array}{c}\text { No. of cif } \\
\text { files }\end{array}$ & $\%$ & $\begin{array}{c}\text { No. of independent } \\
\text { molecules }\end{array}$ & $\%$ \\
\hline Symmetrically substituted —uncomplexed & 25 & 92.6 & 25 & 92.6 \\
\hline Other - uncomplexed & 2 & 7.4 & 2 & 7.4 \\
\hline Total & 27 & 100 & 27 & 100 \\
\hline
\end{tabular}

The $\alpha-\delta$ and $\beta-\delta$ plot of this group are depicted in Figures 32 and 33.

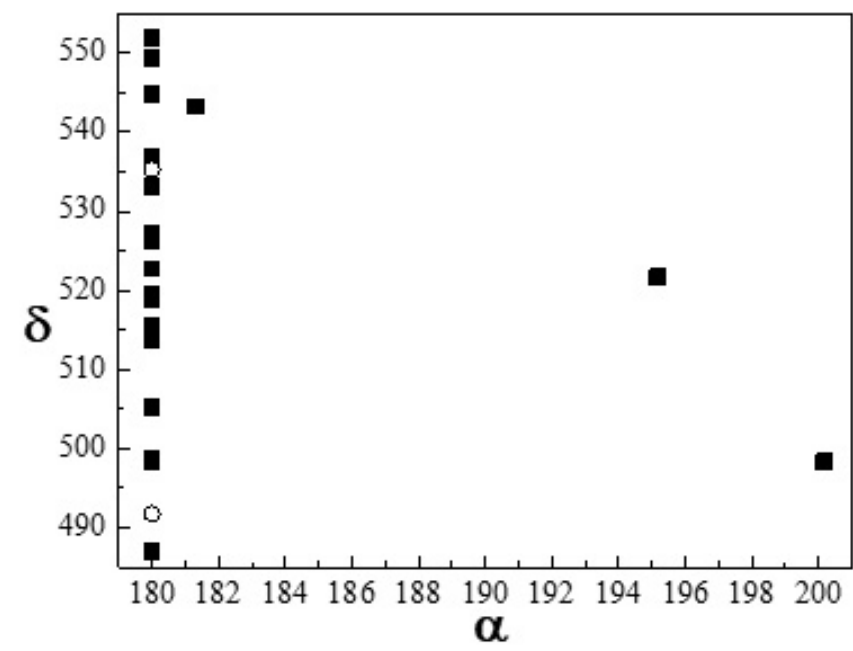

- - symmetrically substituted molecules; ○ — other substitution patterns

Figure 32. The $\alpha-\delta$ plot of the group of 1,2-alternate calix[4]resorcinarenes

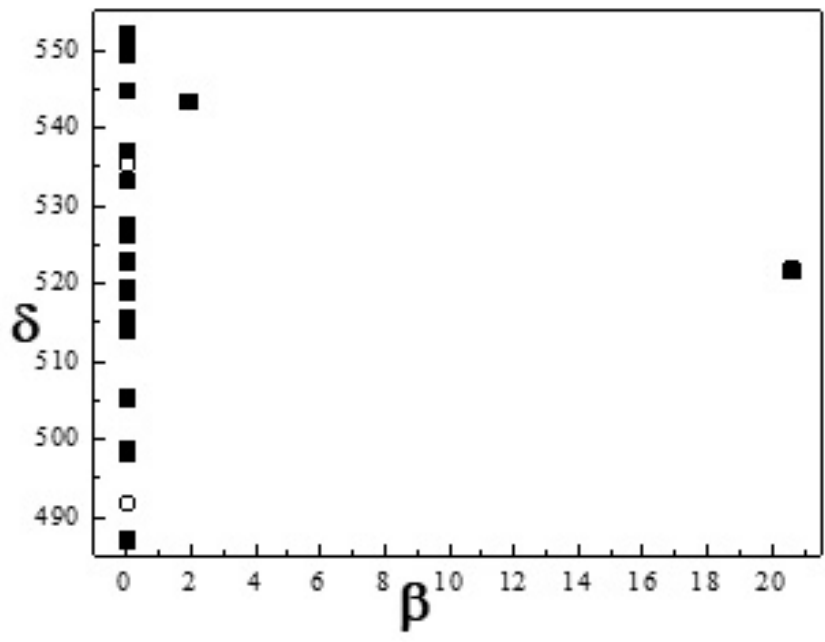

- - symmetrically substituted molecules; ○ — other substitution patterns

Figure 33. The $\beta-\delta$ plot of the group of 1,2 -alternate calix[4]resorcinarenes

From Figure 32 and 33, it is clear that the group of 1,2-alternate resorcinarenes is stretched in the $\delta$ parameter. The majority of structures have $\alpha<182^{\circ}$ and $\beta<2^{\circ}$ ('cluster' 32-I, 25 cif-files with 25 independent molecules, centered at $[180.11 ; 0.15 ; 524.28]$ with standard deviation $[0.36 ; 0.52 ; 17.62])$. However, two structures deviate significantly from this trend. 
Structures of 'cluster' 32-I exist in the chair (flattened partial cone) conformation. This conformation has all substituents on the methylene bridges in the axial positions (up-, up-, down-, down- arrangement); this arrangement minimizes sterical hindrance. Structure PAXREM [9] with unsubstituted methylene bridges adopts this conformation as well. Moreover, all structures with unsubstituted upper rim hydroxy groups tend to form hydrogen bonds to solvent molecules or networks of hydrogen bonds between resorcinarene and/or solvent molecules in the solid state. Other intermolecular interactions ( $\pi, \pi$-interactions with aromatic solvent molecules, $\mathrm{CH}-\pi$ interactions etc.) are also common within this group.

Other interesting feature common for 'cluster' 32-I is the presence of aromatic substituents on the methylene bridges. 13 structures from this group contain this structural motif; in twelve of them there are $\pi, \pi$ interactions between the adjacent aromatic substituents and $\mathrm{CH}-\pi$ interactions between these substituents and one resorcinarene phenyl ring which help further stabilize the conformation (see Fig. 34).

The two structures that significantly deviate from this group (Fig. 32, 33) are structures IFINAM (Fig. 34) and HEFKOS(10) [9]. These structures adopt the diamond conformation with the position of bridge substituents of up-, up-, up-, down-. Both these structures contain aliphatic group-substituted methylene bridges but since there are too few structures in this group, no reliable conclusions can be made.
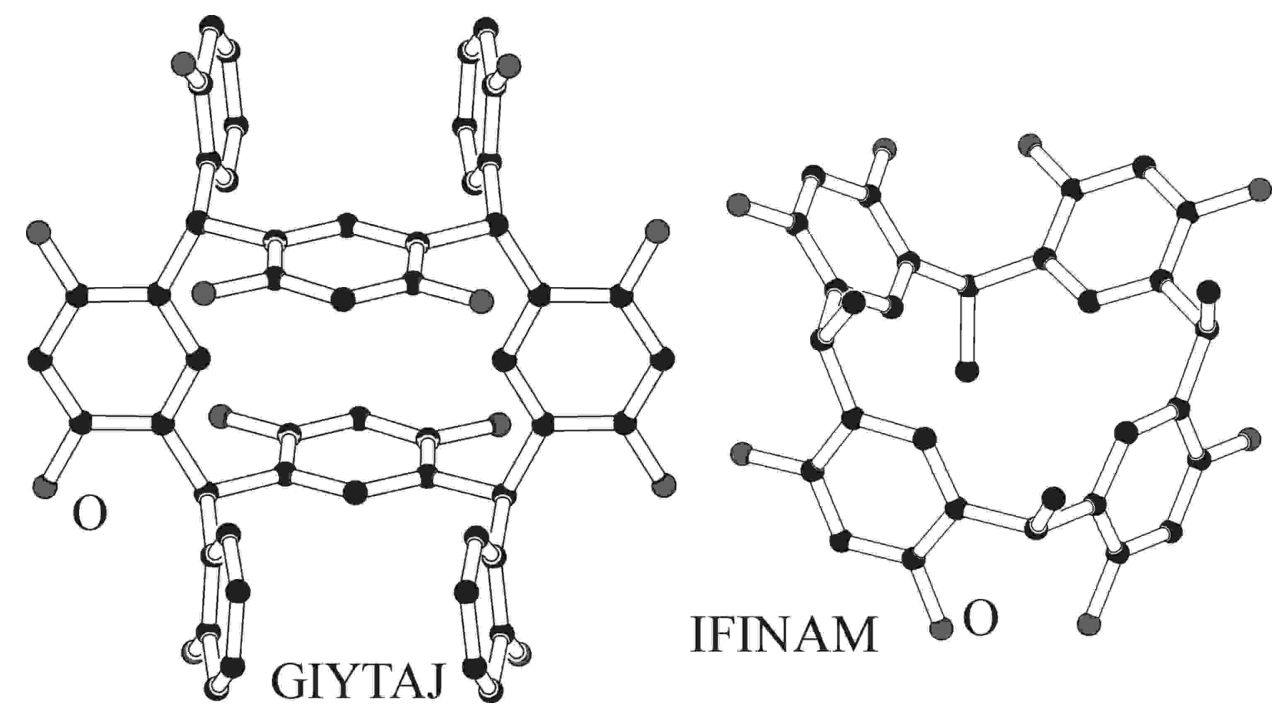

Figure 34. Structure GIYTAJ depicting the typical arrangement of the majority

of 1,2-alternate calix[4]resorcinarenes; structure IFINAM with a more deformed base frame [9]

The structures from 'cluster' 32-I significantly differ in the $\delta$ parameter (range $485-555^{\circ}$ ). Because of the relatively small number of the structures in this group, their diversity and the range of possible inter- and intramolecular interactions in the solid state, no distinct dependence on the type and/or size of the substituents has been observed.

Since 1,2-alternate structures lack cavity, clathrates are not defined. However, there is a large number of inter/intramolecular interactions in the solid state: $\pi, \pi$-interactions and $\mathrm{CH}-\pi$ interactions resorcinarenesolvent (usually aromatic one), hydrogen bonds, intramolecular $\mathrm{CH}-\pi$ interactions between two aromatic bridge substituents and one resorcinarene phenyl rings (and $\pi, \pi$-interactions between the two bridge substituents). The last type occurs in 12 structures in this group (nearly $50 \%$ ). These effects have been discussed earlier in text. Chair-like stacking of calixarene molecules observed previously in 1,2-alternate methylenebridged calix[4]arenes is uncommon in this group; the reason being probably polar and bulky $m$ - substituents on the resorcinarene scaffold.

\section{1,3-alternate calix[4]resorcinarenes}

In the group of 1,3-alternate calix[4]resorcinarenes, there is a relatively large percentage of symmetrically substituted structures (more than $75 \%$, see Table 7).

This group contains 45 cif files with 53 independent molecules; it is significantly more numerous than the groups of 1,2-alternate and partial cone conformers. However, this number still amounts to about $10 \%$ of the cone group. 
Distribution of substitution patterns in the group of 1,3-alternate resorcinarenes from [9]

\begin{tabular}{|l|c|c|c|c|}
\hline \multicolumn{1}{|c|}{ Type } & $\begin{array}{c}\text { No. of cif } \\
\text { files }\end{array}$ & $\%$ & $\begin{array}{c}\text { No. of independent } \\
\text { molecules }\end{array}$ & $\%$ \\
\hline Symmetrically substituted - uncomplexed & 33 & 73.3 & 39 & 73.6 \\
\hline Symmetrically substituted - complex & 1 & 2.2 & 1 & 1.9 \\
\hline Distally substituted - uncomplexed & 3 & 6.7 & 4 & 7.5 \\
\hline Distally substituted - complex & 4 & 8.9 & 5 & 9.4 \\
\hline Other - uncomplexed & 4 & 8.9 & 4 & 7.5 \\
\hline Total & 45 & 100 & 53 & 100 \\
\hline
\end{tabular}

The conformation of the 1,3-alternate calix[4]resorcinarenes in the solid state is based exclusively on the saddle conformation in Figure 1. The position of the bridge substituents is axial; one pair of resorcinarene phenyl rings is close because of intramolecular $\pi, \pi$-interaction (the saddle conformation is very similar to the flattened cone conformation in the partial cone group).

The $\alpha-\beta$ and $\alpha-\delta$ plots for the group of 1,3-alternate calix[4]resorcinarenes are depicted in Figures 35, 36 .

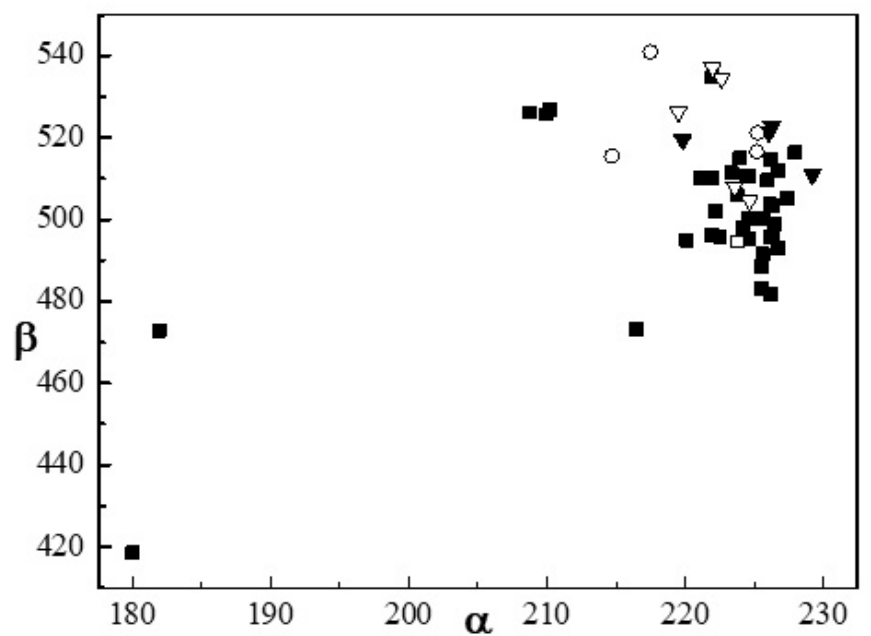

- - symmetrically substituted — uncomplexed; $\square$ - symmetrically substituted — complex;

$\boldsymbol{\nabla}$ - distally substituted - uncomplexed; $\nabla$ — distally substituted — complex; ○ — other substitution patterns)

Figure 35 . The $\alpha-\beta$ plot for the group of 1,3 -alternate calix[4]resorcinarenes

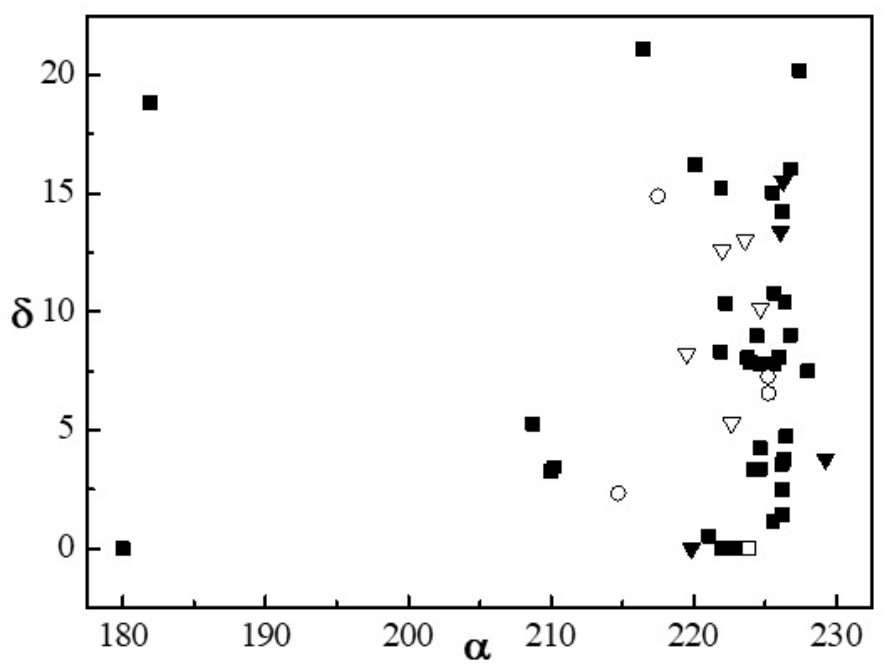

- - symmetrically substituted — uncomplexed; $\square$ - symmetrically substituted — complex;

$\boldsymbol{\nabla}$ — distally substituted — uncomplexed; $\nabla$ — distally substituted — complex; ○ — other substitution patterns

Figure 36. The $\alpha-\delta$ plot for the group of 1,3 -alternate calix[4]resorcinarenes 
In Figure 35, two 'clusters' can be observed: 'cluster' 35-I containing symmetrically substituted structures with $\alpha>220^{\circ}$ and 'cluster' 35-II of distally substituted structures. On the other hand, no distinct 'clusters' can be observed in Figure 36.

'Cluster' 35-I contains 29 cif-files with 34 independent molecules; is centered at $[224.61 ; 502.09 ; 7.15]$ with a standard deviation of $[1.95 ; 10.44 ; 5.34]$. 'Cluster' 35 -II contains 7 cif-files with 9 independent molecules; is centered at $[223.76 ; 520.51 ; 9.11]$ with a standard deviation of $[2.98 ; 10.60 ; 4.88]$.

The group of symmetrically substituted 1,3-alternate calix[4]resorcinarenes ('cluster' 35-I) is quite uniform in $\alpha, \beta$; the structures within the main group adopt the saddle conformation (Fig. 1) with axial bridge substituents. There are several structures in the group of 1,3-alternate calix[4]resorcinarenes which do not fall into this group, especially structures ITIMIH, RIQTAM with parameter $\alpha \sim 180^{\circ}$ (similar value as for 1,3-alternate calix[4]arenes containing methylene bridges). The reason for this behavior is missing bridge substituents and therefore entirely different conformation close to that of 1,3-alternate calix[4]arenes containing methylene bridges (see Fig. 37). Relatively bulky upper rim substituents and the resulting sterical hindrance in the structure ITIMIH and substituted lower rim in the structure RIQTAM might contribute to this behavior as well.

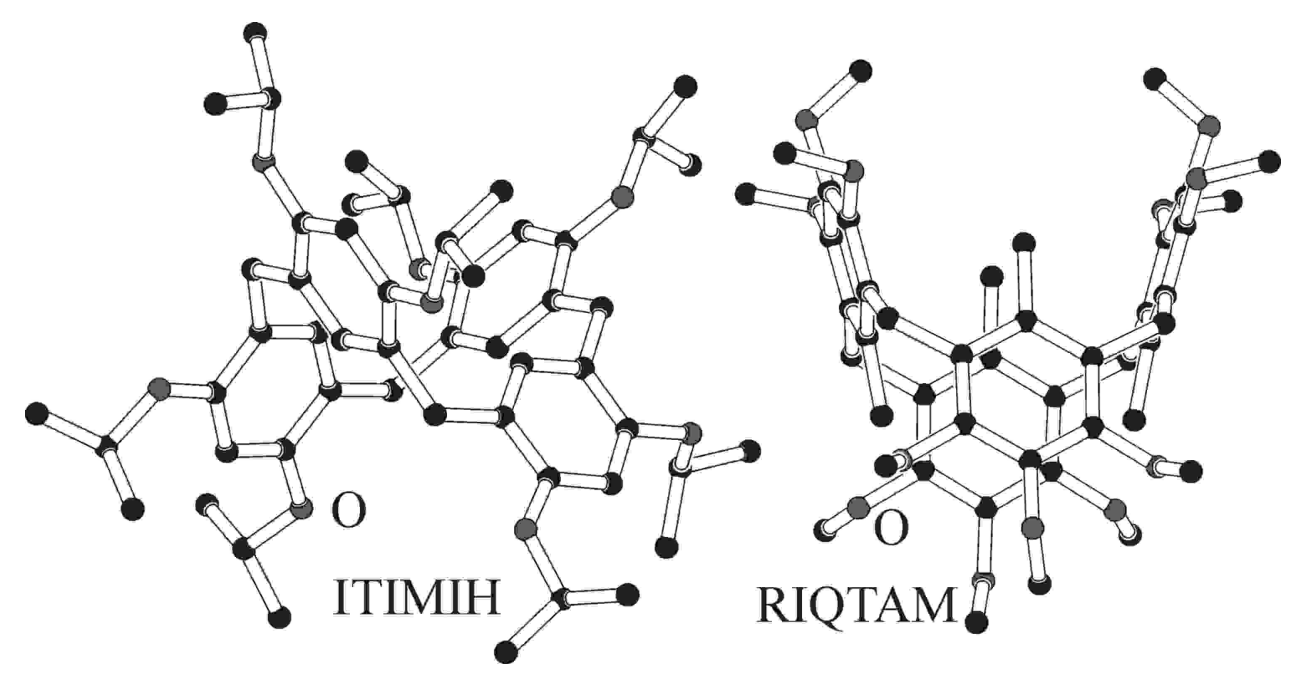

Figure 37. Structures ITIMIH, RIQTAM [9]

However, another structure with missing substituents at the methylene bridges (PAXRAI; the lonely hit at $[216 ; 473]$ in the $\alpha-\beta$ plot) adopts the same conformation as the rest of the symmetrically substituted resorcinarenes. The main reason for this behavior might be the presence of nitro groups at the 5, 11, 17, 23positions of the resorcinarene rings which stabilize the $\pi, \pi$-interactions between two resorcinarene opposite phenyl rings (Fig. 38).

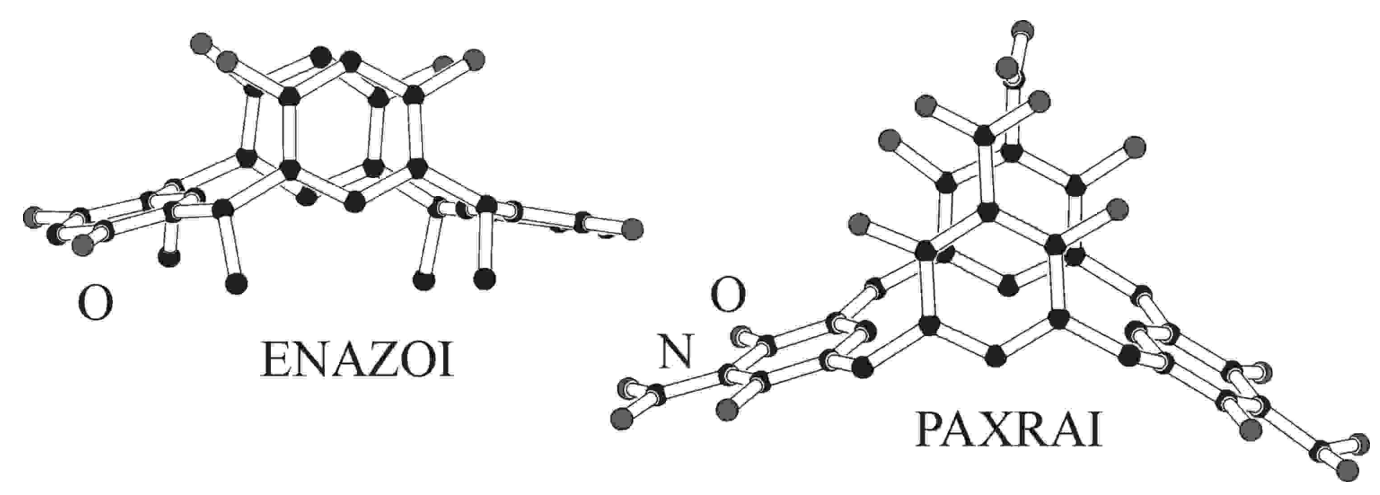

Figure 38. Structures ENAZOI, PAXRAI [9]

There is also a small group of symmetrically substituted structures with $\alpha \sim 210^{\circ}$ which does not fall within 'cluster' 35-I. These structures adopt the base saddle conformation but contain bulky upper rim substituents which disrupt the $\pi, \pi$-interaction between the resorcinarene opposite phenyl rings. The result is 
slightly increased $\beta$ value due to a more open structure; somewhat less significant sterical hindrance has been observed in structure KOGQUS which has high $\beta$ value as well. The rest of the symmetrically substituted structures posses no such effects and the $\pi, \pi$-interaction between the resorcinarene opposite phenyl rings is not disrupted (see structure ENAZOI, Figure 38). However, these structures differ significantly in the $\delta$ parameter (Fig. 36) which is probably a result of intermolecular interactions in the solid state (similar effects as in partial cone and 1,2-alternate groups).

Interestingly, there are also five structures with aromatic substituents at the methylene bridges reported in this group; the resulting $\pi, \pi$-interaction between these substituents helps stabilize the conformation as observed in the 1,2-alternate group.

Since there is only one complex in the symmetrically substituted group, the complexes are not discussed.

The distally substituted group is likewise uniform in $\alpha, \beta$ and differs in $\delta$. The geometry of the resorcinarene base frame corresponds to the saddle conformation in Figure 1 with substituents on the methylene bridges in axial positions. The rules governing the geometry of the resorcinarene base frame seem to be the same as in the case of the symmetrically substituted group. There are also several complexes (four ciffiles with five independent molecules) of similar type coordinated at phosphorus-bearing upper rim substituent within this group; the typical coordination motif is shown on Figure 39.

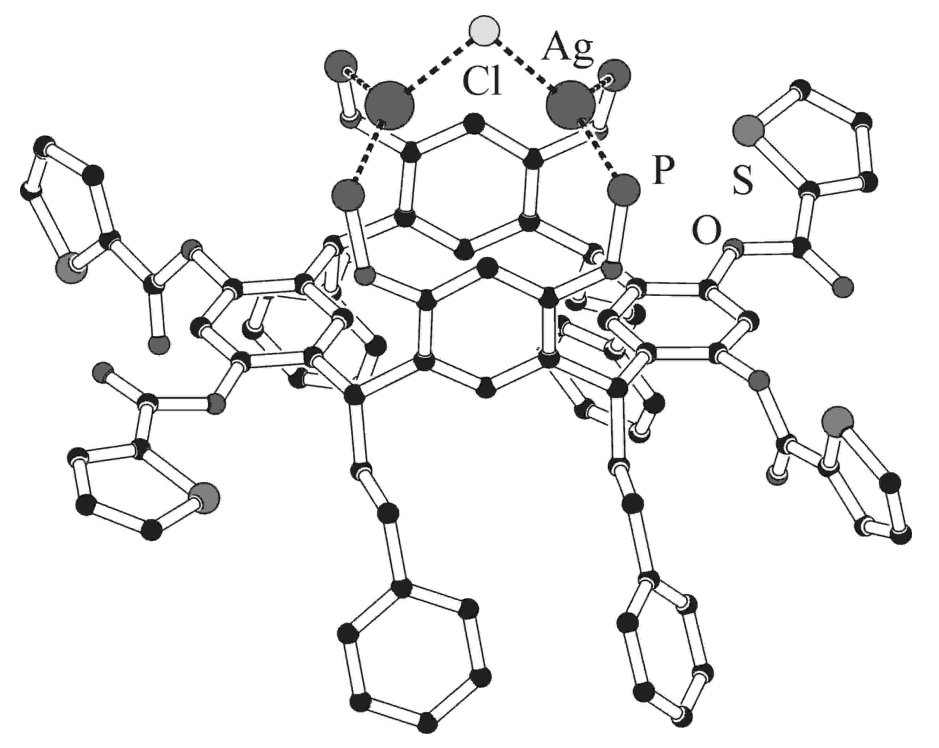

Figure 39. III-17: Structure OMALAP [9]. Phenyl groups on phosphorus atoms have been omitted for clarity

Figure 40 depicts the effect of a filled/empty 'cavity' on the geometry of the 1,3-alternate resorcinarene scaffold. Since the resorcinarene base frame adopts the saddle conformation (Figure 1), it does not possess the two 'cavities' of the methylene- and heteroatom-bridged calix[4]arenes [7, 8]. Furthermore, this conformation restricts the clathrates in such a way that the 'cavity' is usually only partially filled (see e.g. partial cone structures). As a result, the parameter $\beta$ is only slightly increased in the 1,3-alternate clathrates. It seems that the only conformation in resorcinarenes suitable for clathrate formation is the crown one (Fig. 1); the others are ill-suited for this purpose (see clathrates of other conformations).

Since there are not enough structures in this group for discussion, no correlation between the type of the $m$ - and/or $p$-substituents, inter- and/or intramolecular interactions present in the structure and the resorcinarene base frame geometry has been attempted. However, it seems that the vast majority of 1,3-alternate resorcinarenes with substituted methylene bridges tend to adopt a very similar geometry regardless of the base frame substitution; as depicted by uniform parameters $\alpha, \beta$ and only small differences in the $\delta$ parameter.

Application of previously introduced the new parameters $\alpha^{\prime}, \beta^{\prime}, \delta^{\prime}$.

The parameters $\alpha^{\prime}, \beta^{\prime}, \delta^{\prime}$ were introduced in our previous work [13]. The $\alpha^{\prime}-\beta^{\prime}$ and $\alpha^{\prime}-\delta^{\prime}$ plots for the group of calix[4]resorcinarenes are depicted on Figures 41 and 42. 


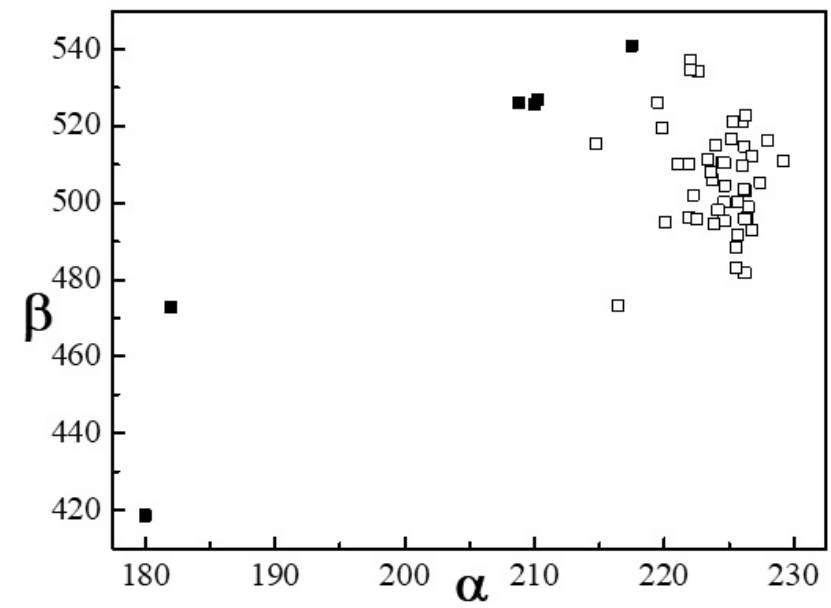

$\square$ - no molecule inside the 'cavity';

- substituent from resorcinarene molecule inside the 'cavity'

Figure 40. The effect of a filled/empty 'cavity' on the symmetry of the 1,3-alternate resorcinarene scaffold

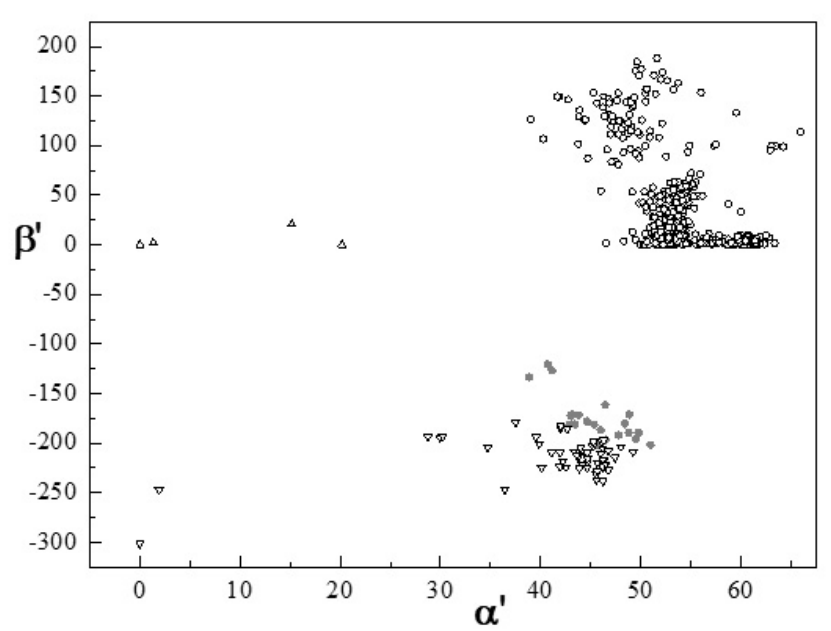

$\circ-$ cone; $\bullet$ - partial cone; $\Delta-1,2$-alternate; $\nabla-1,3$-alternate conformation

Figure 41. The $\alpha^{\prime}-\beta^{\prime}$ plot for the group of calix[4]resorcinarenes

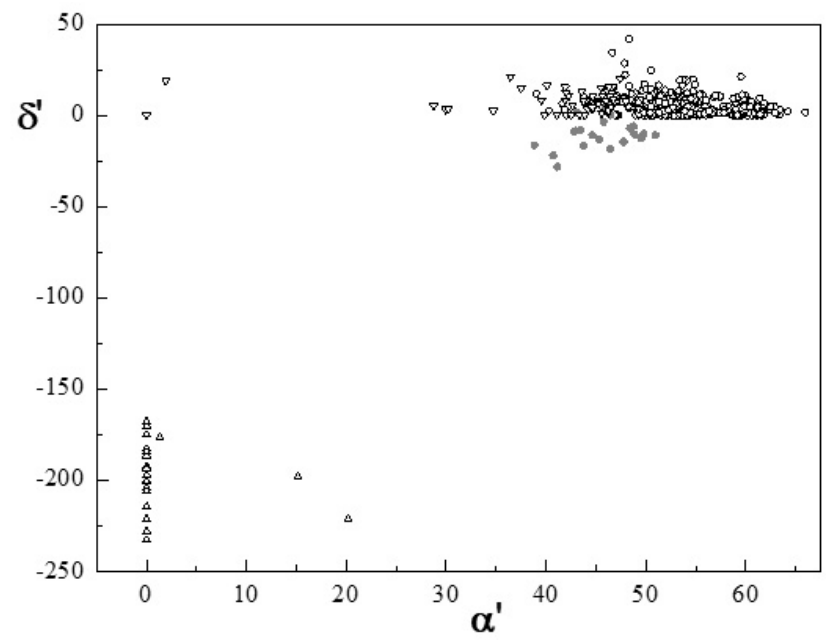

$\circ-$ cone; $\bullet-$ partial cone; $\Delta-1,2$-alternate; $\nabla-1,3$-alternate conformation

Figure 42. The $\alpha^{\prime}-\delta^{\prime}$ plot for the group of calix[4]resorcinarenes 
Since the boat and saddle conformations (Fig. 1) of resorcinarenes are very similar, it is no surprise that the cone, partial cone and 1,3-alternate groups based on these frames are very close. On the other hand, the 1,2-alternate conformation based on entirely different chair or diamond frame (Fig. 1) forms distinct groups in the $\alpha^{\prime}-\delta^{\prime}$ plot.

In the $\alpha^{\prime}-\beta^{\prime}$ plot, two groups among the cone conformers featuring crown and boat geometry can be observed just as in the case of the $\alpha-\beta$ plot (see Fig. 11).

The two 'renegade' hits in the 1,3-alternate group are previously discussed structures ITIMIH, RIQTAM [9] (see Fig. 37; structure IFINAM [9] (Fig. 36) is one of the two 'renegade' hits in the 1,2alternate group.

The differences and similarities between calix[4]arenes with methylene or heteroatom bridges and calix[4]resorcinarenes and between conformers within these groups can be further demonstrated by Table 3 and the corresponding tables in [7]. The similarities between the conformers of calix[4]resorcinarenes (Fig. 1) can be best demonstrated by the $\alpha^{\prime}-\delta^{\prime}$ plot (Fig. 43).

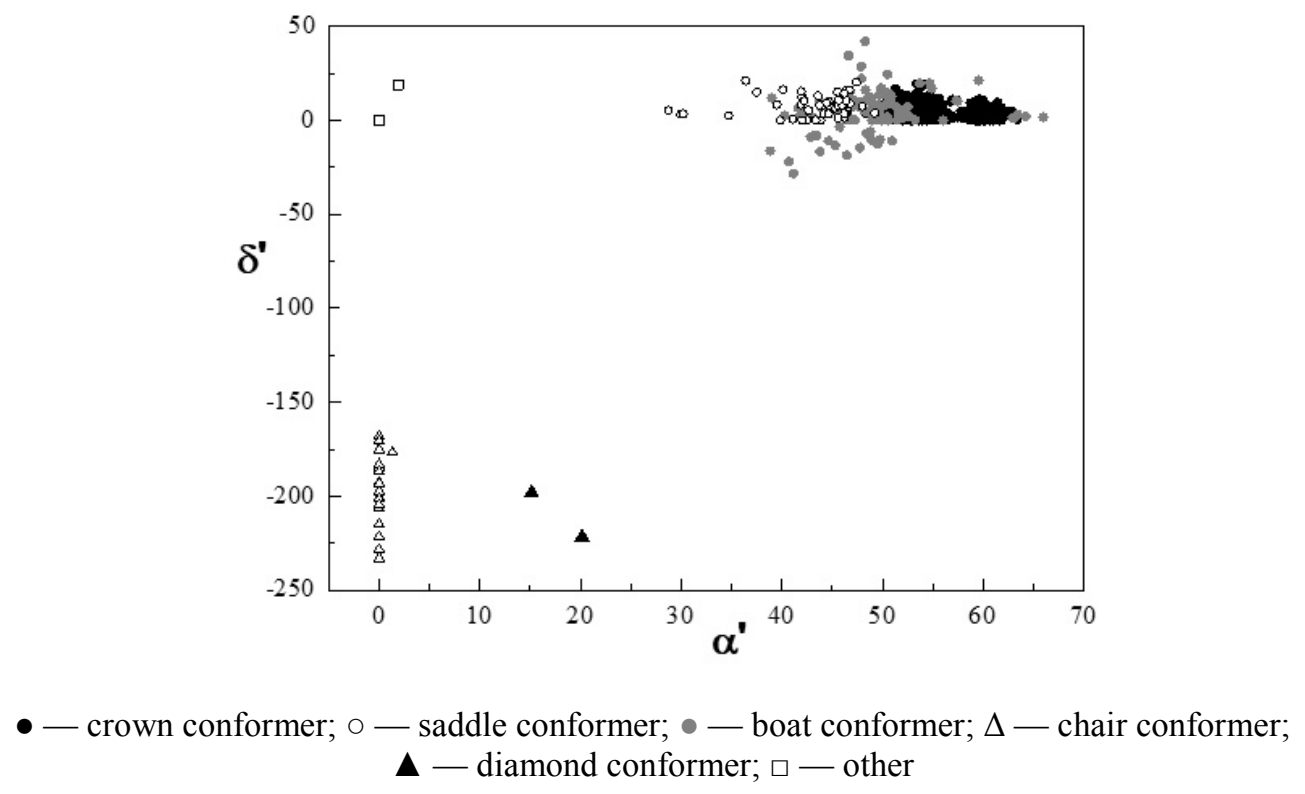

Figure 43. The $\alpha^{\prime}-\delta^{\prime}$ plot for the group of calix[4]resorcinarenes

To sum up, the parameters $\alpha, \beta, \delta$ are useful in describing the geometry of the calix[4]resorcinarene skeleton. These parameters can be not only used to distinguish between the cone, partial cone, 1,2-alternate and 1,3-alternate conformations, their values depend on inter/intramolecular interactions present in the structure as well. The parameters $\alpha, \beta, \delta$ can be therefore utilized to demonstrate and evaluate the effects of inter/intramolecular interactions on the geometry of the calix[4]resorcinarene scaffold. However, since the results were obtained from solid state data, they may not correspond to solution behavior of calix[4]resorcinarene molecules.

We can to try to compare using new parametres $\alpha^{\prime}, \beta^{\prime}, \delta^{\prime}[13]$ for calix[4]resorcinarene systems, too. These newly introduced ones are convenient mainly for describing similarities and 'transition states' between the calix[4]arene conformations (see [13]). However, in the group of calix[4]resorcinarenes where a large number of similar structures are present (see the boat and saddle conformations in Fig. 1), these parameters seem to be less useful because the desired effects are blurred and the groups belonging to distinct conformations cannot be observed (see Fig. 42). In the case of calix[4]resorcinarenes, parameters $\alpha, \beta, \delta$ based on the original scale are probably more convenient.

\section{Conclusion}

In conclusion, the best way to $\mathrm{C}_{4 \mathrm{v}}$-symmetrical cone calix[4]resorcinarenes is bridging of the upper rim $m$ - hydroxy groups by methylene or heteroatom (principally phosphorus)-based groups. The resulting frame is very rigid, readily forms clathrates and in the case of phosphorus-bridged compounds can be easily coordinated by metal ions. Coordination of adjacent unsubstituted $m$-hydroxyl groups by four metal ions has 
similar effect. There seems to be no other way to invariably prepare resorcinarenes in the crown conformation.

On the other hand, substitution of all $m$-hydroxyl groups by monodentate alkyl or acyl groups and distal substitution of all $m$-hydroxyl groups of two opposite resorcinarene phenyl rings have always resulted in flattened cone structures.

Structures with unsubstituted $m$ - hydroxyl groups tend to have more symmetrical structures than structures with these groups substituted thanks to a stabilizing array of hydrogen bonds; especially in the case of a filled cavity. Clathrates of these molecules tend to have more symmetrical base frames than molecules with an empty cavity, as observed before $[7,8]$. Clathrates close to $\mathrm{C}_{4 \mathrm{v}}$ geometry usually contain small aliphatic molecules with $\mathrm{C}_{>2}$ axis inside the calixarene cavity; flat aromatic clathrate molecules usually result in a structure deformed towards $\mathrm{C}_{2 \mathrm{v}}$ geometry. Bulky $p$ - substituents combined with unsubstituted $m$-hydroxyl groups usually result in a slightly deformed $\mathrm{C}_{4 \mathrm{v}}$ geometry.

More flexible $m$-bridges containing two or more carbon atoms can result in both $\mathrm{C}_{4 \mathrm{v}}$ and $\mathrm{C}_{2 \mathrm{v}}$ structures; the determining effect being the presence/absence of solvent molecule inside the resorcinarene cavity.

Metal coordination usually takes place on upper rim $p$ - or $m$-substituents and in most cases does not significantly affect the resorcinarene conformation. On the other hand, distally coordinated symmetrically substituted structures with unsubstituted $m$-hydroxyl groups and complexes of structures distally substituted at $m$-hydroxyl groups tend to have $\mathrm{C}_{2 \mathrm{v}}$ geometry.

Inter- and/or intramolecular interactions resulting in increase of $\delta$ parameter cannot be easily described and were therefore not taken into account.

Since there are not enough molecules in other conformations (partial cone, 1,2- and 1,3-alternate), these structures will not be explicitely discussed.

\section{Acknowledgements}

We thank RNDr. Ivana Císařová, CSc. for the provision of CSD data. Access to the Cambridge Crystallographic Data Centre was sponsored by the Grant Agency of the Czech Republic (grant No. 203/99/0067). We thank Dr. Ye. Minayeva for her help with Russian part of text. We thank Dr. L. Zhaparova for her help with Kazakh part of text.

\section{References}

1 Gutsche, C.D. (1989). Calixarenes: Monographs in Supramolecular Chemistry, Cambridge, Royal Society of Chemistry.

2 Wieser, C., Dieleman, C.B., \& Matt, D. (1997). Calixarene and resorcinarene ligands in transition metal chemistry. Coordination Chemistry Reviews, 165, 93-161.

3 Higler, I., Timmerman, P., Verboom, W., \& Reinhoudt, D.N. (1998). The Modular Approach in Supramolecular Chemistry. Eur. J. Org. Chem, 1998(12), 2689-2702.

4 Stoddart, J.F., Timmerman, P., Verboom, W., \& Reinhoudt, D.N. (1996). Resorcinarenes. Tetrahedron, 52(8), $2663-2704$.

5 Macrocycle Synthesis. (1996). Ed. by D. Parker. New York, Oxford University Press.

6 Saito, S., Rudkevich, D.M., Rebek, J. (n. a.). Lower Rim Functionalized Resorcinarenes: Useful Modules for Supramolecular Chemistry Org. Lett., 1(8), 1241-1244.

7 Klimentová, J., Mádlová, M., Němečková, P., Palatinusová, L., Vojtíšek, P., \& Lukeš, I. (2017). Conformations of calix[4]arenes - an investigation based on CSD data. Part I. Cone conformers of methylene- and heteroatom-bridged calix[4]arenes. Bulletin of the Karaganda University. Ser. Chemistry, 85(1), 21-46.

8 Klimentová, J., Mádlová, M., Němečková, P., Palatinusová, L., Vojtíšek, P., \& Lukeš, I. (2017). Conformations of calix[4]arenes - an investigation based on CSD data. Part II. Partial cone, 1,2-alternate and 1,3-alternate conformers of methyleneand heteroatom-bridged calix[4]arenes. Bulletin of the Karaganda University. Ser. Chemistry, 88(4), 8-38.

9 CSD Version 2.3.6 (update August 2006), Cambridge Crystallographic Data Centre (CCDC).

10 Lhoták, P. (2004). Chemistry of Thiacalixarenes. Eur. J. Org. Chem., 2004(8), 1675-1692 (and references therein).

11 Klimentová, J., \& Vojtíšek, P. (2005). Stereochemistry of calix[4]arenes. Materials Struct., 12, 151.

12 Klimentová, J., \& Vojtíšek, P. (2007). New receptors for anions in water: Synthesis, characterization, X-ray structures of new derivatives of 5,11,17,23-tetraamino-25,26,27,28-tetrapropyloxycalix[4]arene. J. Mol. Struct., 826(1), 48-63.

13 Klimentová, J., \& Vojtíšek, P. (2018). Variation of the stereoparameters for description geometry of calix[4]arenes - more suitable solution for «flat systems». Bulletin of the Karaganda University. Ser. Chemistry, 90(2), 23-30. 


\title{
Я. Климентова, И. Лукеш, П. Войтишек
}

\section{Каликс[4]арендердің конформациялары. CSD мәліметтеріне негізделген зерттеулер. III-бөлім. Каликс[4]резорцинарендер}

\begin{abstract}
Бұл зерттеудің I-бөлімінде каликс[4]арендердің метиленді және Кембридждің құрылымдық мәліметтер базасының гетероатомды көпіршелерімен (CSD) коникалық конформерлері зерттелген. II-бөлімінде каликс[4]арендердің 1,2-альтернантты және 1,3-алтернантты жартылай құрылымды конустың метиленді және гетероатомды көпіршелерге көңіл бөлінді. Шолудың III-бөлімі бұған дейін жасалған зерттеулердің жалғасы болып келеді және ол каркасты каликс[4]резорцинарендердің конформациясы мен геометриясын Кембридждің құрылымдық мәліметтер базасының қолдана отырып зерттеуге арналады. Нәтижелер бұған дейін біздің зерттеуімізде алынған каликс[4]арендерді құрылымдардың мәліметтерімен салыстырылды. Резорцинаренді негіздердің құрылымындағы симметрия бойынша молекулааралық әрекеттесулер мен орынбасу әсерлері бұған дейін енгізілген стереохимиялық $\alpha, \beta$ және $\delta$ параметрлері арқылы бағаланды. Сонымен қатар жаңа, сәл өзгертілген $\alpha^{\prime}$, $\beta^{\prime}, \delta$ параметрлер шкаласын қолдану тексерілді. Қорытындылай келе, бұл параметрлердің тек каликс[4]арендердің геометриясын сипаттау үшін ғана емес, сонымен қоса, каликс[4]резорцинарендер үшін де пайдалы екенін айта кету керек. Каликс[4]резорцинарендер конформациялық жағынан иілгіштігі жоғары болса керек, сондықтан оларға «жазықтықтық» орналасу тән. Әдетте, каликс[4]резорцинарендер үшін орынбасу әлдеқайда күрделі және ретсіз болады, сондықтан жалпы заңдылық табу қиынға түседі. Алайда алынған нәтижелер қатты дене күйінің мәліметтерінен алынғандықтан, бұл молекулалардың ерітіндідегі күйі мен конформациясы туралы каликс[4]арендер сияқты тұжырым жасауға болмайды.
\end{abstract}

Кілт сөздер: рентгенді құрылымдарды анықтау, Кембридждің құрылымдық мәліметтер базасы (CSD), каликс[4]резорцинарендердің стереохимиясы, конформациялар, дисторсия параметрлері, симметрия, орынбасу модельдері, негізгі каркасының бұзылуы.

\section{Я. Климентова, И. Лукеш, П. Войтишек}

\section{Конформации каликс[4]аренов. Исследование, основанное на данных CSD. Часть III. Каликс[4]резорцинарены}

\begin{abstract}
В первой части этого исследования были изучены конические конформеры каликс[4]аренов с метиленовыми и гетероатомными мостиками из Кембриджской структурной базы данных (CSD), во второй части мы сосредоточились на структурах частичного конуса, 1,2-альтернантных и 1,3-альтернантных конформерах каликс[4]аренов с метиленовыми и гетероатомными мостиками. Данная третья часть обзора является продолжением первых двух, она посвящена конформациям и геометрии каркасных каликс[4]резорцинаренов. Результаты были сопоставлены с данными каликс[4]ареновых структур в наших предыдущих работах. Эффекты замещений и межмолекулярных взаимодействий, присутствующих в структуре по симметрии резорцинареновой основы, оценивались с помощью ранее введенных стереохимических параметров $\alpha, \beta$ и $\delta$. Было также проверено использование новой, слегка измененной шкалы параметров $\alpha^{\prime}, \beta^{\prime}, \delta^{\prime}$. Подводя итог, следует отметить, что эти параметры полезны не только для описания геометрии каликс[4]аренов, но и для каликс[4]резорцинаренов. Каликс[4]peзорцинарены, по-видимому, более конформационно гибкие, и для них предпочтительнее «плоские» расположения. Как правило, замещение является более сложным и более нерегулярным в случае каликс[4]резорцинаренов, и найти некоторые общие закономерности относительно сложно. Однако, поскольку все эти результаты были получены из данных о состоянии твердого тела, нельзя сделать вывод о конформациях и поведении этих молекул в растворе, аналогичных, как в случае каликс[4]аренов.
\end{abstract}

Ключевые слова: определение рентгеновских структур, Кембриджская структурная база данных (CSD), стереохимия каликс[4]резорцинаренов, конформации, параметры дисторсии, симметрия, модели замещения, деформация базового каркаса. 